\title{
Sustainability characteristics of drinking water supply in the Netherlands
}

\author{
Jolijn van Engelenburg ${ }^{1}$, Erik van Slobbe ${ }^{2}$, Adriaan J. Teuling ${ }^{3}$, Remko Uijlenhoet ${ }^{3,4}$, and \\ Petra Hellegers ${ }^{5}$ \\ ${ }^{1}$ Asset Management Department, Vitens NV, P.O. Box 1205, 8001 BE Zwolle, the Netherlands \\ ${ }^{2}$ Water Systems and Global Change Group, Wageningen University and Research, \\ P.O. Box 47, 6700 AA Wageningen, the Netherlands \\ ${ }^{3}$ Hydrology and Quantitative Water Management Group, Wageningen University and Research, \\ P.O. Box 47, 6700 AA Wageningen, the Netherlands \\ ${ }^{4}$ Department of Water Management, Civil Engineering and Geosciences Faculty, Delft University of \\ Technology, P.O. Box 5048, 2600 GA Delft, the Netherlands \\ ${ }^{5}$ Water Resources Management Group, Wageningen University and Research, \\ P.O. Box 47, 6700 AA Wageningen, the Netherlands
}

Correspondence: Jolijn van Engelenburg (jolijn.vanengelenburg@ vitens.nl)

Received: 13 March 2020 - Discussion started: 24 March 2020

Revised: 16 October 2020 - Accepted: 29 November 2020 - Published: 19 January 2021

\begin{abstract}
Developments such as climate change and a growing demand for drinking water threaten the sustainability of drinking water supply worldwide. To deal with this threat, adaptation of drinking water supply systems is imperative, not only on a global and national scale but particularly on a local scale. This investigation sought to establish characteristics that describe the sustainability of local drinking water supply. The hypothesis of this research was that sustainability characteristics depend on the context that is analysed, and therefore, a variety of cases must be analysed to reach a better understanding of the sustainability of drinking water supply in the Netherlands. Therefore, three divergent cases on drinking water supply in the Netherlands were analysed. One case related to a short-term development (2018 summer drought), and two concerned long-term phenomena (changes in water quality and growth in drinking water demand). We used an integrated systems approach, describing the local drinking water supply system in terms of hydrological, technical, and socio-economic characteristics that determine the sustainability of a local drinking water supply system. To gain a perspective on the case study findings that are broader than the Dutch context, the sustainability aspects identified were paired with global aspects concerning sustainable drinking water supply. This resulted in the following set of hydrological, technical, and socio-economic sustainability characteristics: (1) water quality, water resource availability, and impact of drinking water abstraction; (2) reliability and resilience of the technical system and energy use and environmental impact; (3) drinking water availability, water governance, and land and water use. Elaboration of these sustainability characteristics and criteria into a sustainability assessment can provide information on the challenges and trade-offs inherent in the sustainable development and management of a local drinking water supply system.
\end{abstract}




\section{Introduction}

Climate change, combined with a growing drinking water demand, threatens the sustainability of the drinking water supply worldwide. The goal set for drinking water supply in Sustainable Development Goal (SDG) 6.1 (UN, 2015) is "to achieve universal and equitable access to safe and affordable drinking water for all by 2030 ". Worldwide drinking water supply crises are visible, resulting from a combination of limited water resource availability, lacking or failing drinking water infrastructure, and/or increased drinking water demand due to short-term events or long-term developments (WHO, 2017). Still, nearly 10 percent of the world population is fully deprived of improved drinking water resources (Ekins et al., 2019), and additionally, existing drinking water supply systems are often under pressure. For instance, two recent examples of water crises were reported in Cape Town, South Africa, and São Paolo, Brazil (Sorensen, 2017; Cohen, 2016). To deal with such challenges and threats to safe and affordable drinking water, adaptation of the current drinking water supply system is imperative, not only on a global and national level but also on a local scale.

In the Netherlands, for instance, the national drinking water supply currently meets the indicator from SDG 6 (UN, 2018) on safely managed drinking water services and safely treated wastewater. At the same time, the more specific goals on (local) water quantity, quality, and ecology, as set by the European Water Framework Directive (WFD), are not met yet (European Environment Agency, 2018). Consequently, drinking water supply in the Netherlands does not meet all SDG 6 indicators, for instance when considering impact on water-related ecosystems (Van Engelenburg et al., 2018), of water pollution (Kools et al., 2019; Van den Brink and Wuijts, 2016), or of water shortage (Ministry of Infrastructure and Environment and Ministry of Economic Affairs and Climate Policy, 2019). Additionally, future developments, such as the uncertain drinking water demand growth rate (Van der Aa et al., 2015) and the changing climate variability (Teuling, 2018), may put the sustainability of the Dutch drinking water supply under pressure in the future.

The abstraction of groundwater or surface water from the hydrological system, and subsequent treatment to drinking water quality before being distributed to customers, requires local infrastructure (typically a drinking water production facility embedded in a distribution network of pipelines). Although the daily routine of drinking water supply has a highly technical character (Bauer and Herder, 2009), the sustainability in the long-term depends on the balance between technical, socio-economic, and environmental factors. This balance is especially complex for the local drinking water supply, which is intertwined with the local hydrological system and local stakeholders through its geographical location.

Because of the interconnections between physical, technical, and socio-economic factors as well as across space, organizational levels, and time, adaptation of the local drink- ing water supply to current and future sustainability challenges calls for an integrated planning approach (Liu et al., 2015). Integrated models have been developed to understand the complex interactions between the physical, technical, and socio-economic components in various water systems (Loucks et al., 2017). However, a systems analysis to assess local drinking water supply and to identify sustainability challenges on a local scale has not yet been developed.

This research aimed to propose a set of sustainability characteristics that describe the drinking water supply system on a local scale to support policy- and decision-making on sustainable drinking water supply. To reach this aim, cases on drinking water supply were analysed using a conceptual framework. The selected cases represented a short-term event and long-term developments that affect water quality and water resource availability, the technical drinking water supply infrastructure, and/or the drinking water demand. The system boundaries were set to drinking water supply on a local scale. While the drinking water supply on a local scale is also affected by outside influences from different organizational and spatial scales, the analysis accounted for these external influences too. The hypothesis of this research was that sustainability characteristics depend on the context that is analysed, and therefore, a variety of cases must be analysed to reach a better understanding of the sustainability of drinking water supply in the Netherlands.

\section{Method}

Sustainable water systems can be defined as water systems that are designed and managed to contribute to the current and future objectives of society, maintaining their ecological, environmental, and hydrological integrity (Loucks, 2000). This study focused on the sustainability of drinking water supply systems on a local scale - in short, local drinking water supply systems. The boundaries of these systems were set by the area in which drinking water abstraction is embedded. The system can be approached from different perspectives. The socio-ecological approach considers relations between the socio-economic and environmental system, whereas the socio-technical approach considers the socio-economic and technical system (Pant et al., 2015). In this study, we combined both approaches by describing the local drinking water supply system in terms of hydrological, technical, and socioeconomic characteristics that determine the sustainability of a local drinking water supply system.

Drinking water supply in the Netherlands is of a high standard compared to many other countries. The SDG 6 targets on safe and affordable drinking water and sanitation and wastewater treatment are basically met. But the Dutch government and drinking water suppliers are also challenged to meet the other goals set in SDG 6, such as the improvement of water quality, increase in water-use efficiency, and protection and restoration of water-related ecosystems. In ad- 
dition the standards on water quantity, quality, and ecology, as set by the European Water Framework Directive (WFD), have not been achieved yet (European Environment Agency, 2018).

The adopted research approach consisted of four steps. The first step was the selection and analysis of three drinking water practice cases in the Netherlands, aiming to identify the main Dutch sustainability aspects in these cases. Three Dutch cases were selected based on their impact on the sustainability of drinking water supply in the Netherlands, considering a short-term event with limited water resource availability and long-term, ongoing developments on water quality, and growing drinking water demand and water resource availability. The cases are illustrated with Vitens data (Van Engelenburg et al., unpublished, 2020).

In the second step, the cases were analysed using the DPSIR framework (Driver, Pressure, State, Impact, Response; Eurostat, 1999; see Sect. 2.1). The sustainability aspects of these cases were identified in the descriptive results of the DPSIR analysis. The results were combined with Dutch governmental reports on these events and developments (Ministry of Infrastructure and Environment and Ministry of Economic Affairs and Climate Policy, 2019; Vitens, 2016) and cross-checked with Vitens staff. The sustainability aspects were categorized into hydrological, technical, and socioeconomic aspects. This resulted in a set of relevant sustainability aspects, which is presented in Appendices A-C. The following step was used to broaden the perspective from the drinking water supply in the Netherlands to a more general perspective by cross-checking the set of sustainability aspects with the targets and indicators in Sustainable Development Goal 6 (hereafter referred to as SDG 6; see Appendix D; UN, 2015) and the WHO Guidelines for Drinkingwater Quality (WHO, 2017). The sustainability aspects, as identified in the analysis, were categorized into nine hydrological, technical, and socio-economic sustainability characteristics. In the final step of the study, each sustainability characteristic was elaborated further into five sustainability criteria that describe the local drinking water supply system. The results are described in Sect. 3. A detailed description of the resulting sustainability criteria is presented in Appendix E.

\subsection{Case analysis method}

To reach the aim of this research to support policy development on sustainable drinking water supply, three practice cases were analysed to identify the main sustainability aspects in these cases using the DPSIR (Driver, Pressure, State, Impact, Response) systems approach (Eurostat, 1999). Drivers describe future developments, such as climate change and population growth. Pressures are developments (in emissions or environmental resources) as a result of the drivers. The state describes the system state that results from the pressures. In this research, the aim is to describe the sys- tem state of the drinking water supply system in terms of local hydrological, technical, and socio-economic sustainability characteristics (see Sect. 2.1). The changes in system state cause impacts on system functions, which will lead to societal responses. DPSIR was originally developed to describe causal relations between human actions and the environment. It has also frequently been used for relations and interactions between technical infrastructure and the socio-economic and physical domain (Pahl-Wostl, 2015; Hellegers and Leflaive, 2015; Binder et al., 2013).

The DPSIR approach was used for the analysis of the three selected drinking water supply cases to obtain an overview of the impact of drivers, pressures, and responses to the state of the drinking water supply system. Although the framework has been applied on different spatial scales, Carr et al. (2009) recommend using the framework in a place-specific manner to ensure that local stakeholder perspectives are assessed as well. With the research focus at the local drinking water supply system, these local perspectives were implicitly included. The drivers, pressures, and responses can be on local and higher organizational and/or spatial scales, thus ensuring that - where essential - relevant higher scales are accounted for too.

DPSIR has previously been used for complex water systems by various well-known researchers in this field, such as Claudia Pahl-Wostl. In Binder et al. (2013), a comparison was made between various frameworks, which concluded that DPSIR is a policy framework that does not explicitly include development of a model but aims at providing policyrelevant information on pressures and responses on different scales. In Carr et al. (2009), the use of DPSIR for sustainable development was evaluated. Although the authors were critical regarding the use of the DPSIR framework on national, regional, or global scales, they considered application on a local scale appropriate. They concluded that practitioners could use DPSIR for local-scale studies because it assesses the place-specific nuances of multiple concerned stakeholders more realistically. In Van Noordwijk et al. (2020), DPSIR was used to understand the joint multiscale phenomena in the forest-water-people nexus and, thus, diagnosed issues to be addressed in local decision-making. Therefore, DPSIR was considered an appropriate framework for meeting the aim of the research.

The impact of developments on different temporal scales to the drinking water supply system must be considered as well. The long-lived, interdependent drinking water supply infrastructure is resistant to change due to design decisions in the past which cause path dependencies and lock-ins (Melese et al., 2015). In addition, consumer behaviour, governance and engineering, and the interaction between these processes cause lock-in situations that limit the ability to change towards more sustainable water resources management (PahlWostl, 2002). For this reason, the case analysis was performed considering both short- and long-term pressures, impacts and responses. 


\subsection{Case selection}

In this research, three drinking water supply cases in the Netherlands were selected. The case studies were analysed to find sustainability aspects caused by the identified pressures and short- and/or long-term responses in each case because short-term shocks have different impacts and call for other responses than long-term stresses (Smith and Stirling, 2010). The cases therefore focused on short-term events and longterm developments. All three cases also related to targets set in SDG 6 (UN, 2015). The DPSIR analysis of the case studies is presented in Appendices A-C.

\subsection{Case 1: 2018 summer drought}

Summer 2018 in the Netherlands was extremely warm and dry, causing water shortages in the water system and a long period of extreme daily drinking water demand, resulting in a record monthly water demand in July 2018 (Ministry of Infrastructure and Environment and Ministry of Economic Affairs and Climate Policy, 2019; see Illustration case 1). The driver in this case is the extreme weather condition, which caused several pressures, such as high temperatures, high evaporation, and a lack of precipitation. These pressures did not only cause drought damage to nature, agriculture, and gardens and parks as well as limited water availability in the surface water and groundwater systems, they also resulted in an extremely high drinking water demand. Data on drinking water supply volumes (Van Engelenburg et al., unpublished, 2020) showed that the extreme drinking water demand during summer 2018 put the drinking water supply system under high pressure, causing extreme daily and monthly drinking water supply volumes that exceeded all previously supplied volumes (see Fig. 1). The capacity of the system was fully exploited but faced limitations in abstraction, treatment and distribution capacity.

\section{Illustration case 1: 2018 summer drought}

Within the Vitens supply area, the average daily supply volume during the summer period June-August over the years 2012-2017 was approximately $965000 \mathrm{~m}^{3} \mathrm{~d}^{-1}$. During the period 27 June-4 August 2018, the daily supply volume exceeded this average summer volume by approximately $28 \%$, with an average volume of nearly $1240000 \mathrm{~m}^{3} \mathrm{~d}^{-1}$ (Fig. 1a). On 25 July 2019, the maximum daily water supply reached nearly $1390000 \mathrm{~m}^{3} \mathrm{~d}^{-1}$, which was $42 \%$ above the baseline daily supply (Fig. 1a). The monthly drinking water supply volume in July 2018 of 38 million $\mathrm{m}^{3}$ per month was an increase of $18 \%$ compared to the previous maximum monthly supply volumes (Fig. 1b). Although the drinking water supply infrastructure was designed with an overcapacity to meet the regular demand peaks, the flexibility to more extreme peaks or to long periods of peak demand is limited.

The high drinking water abstraction volumes added up to the water shortages in both the groundwater and the surface water system that was caused by the lack of precipitation and high evaporation during the summer (Ministry of Infrastructure and Environment and Ministry of Economic Affairs and Climate Policy, 2019). To ensure an acceptable surface water quality for the drinking water supply, measures were taken to reduce salinization (Ministry of Infrastructure and Environment and Ministry of Economic Affairs and Climate Policy, 2019).

To reduce the drinking water use, a call for drinking water saving was made, and locally, pressures in the drinking water distribution system were intentionally lowered to reduce the delivered drinking water volumes (Ministry of Infrastructure and Environment and Ministry of Economic Affairs and Climate Policy, 2019). The problems caused by the summer drought raised a discourse on (drinking) water use and saving, including discussions on controversial measures such as a progressive drinking water tariffs, with tariffs dependent on the consumed drinking water volume and differentiation between high-grade and low-grade use of (drinking) water (Ministry of Infrastructure and Environment and Ministry of Economic Affairs and Climate Policy, 2019). The results of this case analysis are presented in Appendix A.

\subsection{Case 2: groundwater quality development}

This case focused on the impact of the groundwater quality development in the Netherlands on the drinking water supply. Analysis of the state of the resources for drinking water supply in the Netherlands in 2014 pointed out that, although the drinking water quality met the Dutch legal standards, all water resources are under threat by known and new pollutants (Kools et al., 2019). In the Netherlands, $55 \%$ of the drinking water supply is provided by groundwater resources (Baggelaar and Geudens, 2017). Long-term analysis of water quality records of Dutch drinking water supply fields shows that the vulnerability of groundwater resources to external influences, such as land use, strongly depends on hydrochemical characteristics (Mendizabal et al., 2012). Monitoring results show that, currently, groundwater quality is mainly under pressure due to nitrate, pesticides, historical contamination, and salinization (Kools et al., 2019). Nearly half of the groundwater abstractions for drinking water are affected by an insufficient groundwater quality, and it is expected that, in the future, the groundwater quality at more abstractions will exceed the groundwater standards set in the European Water Framework Directive (European Union, 2000). In addition, traces of pollutants such as recent industrial contaminants, medicine residues, and other emerging substances have been found, indicating that the groundwater quality will likely further deteriorate (Kools et al., 2019).

Groundwater protection regulations regarding land and water use by legal authorities will help to slow down groundwater deterioration (Van den Brink and Wuijts, 2016). However, strategies to restore groundwater quality will often not be effective in the short term because already existing con- 
(a)

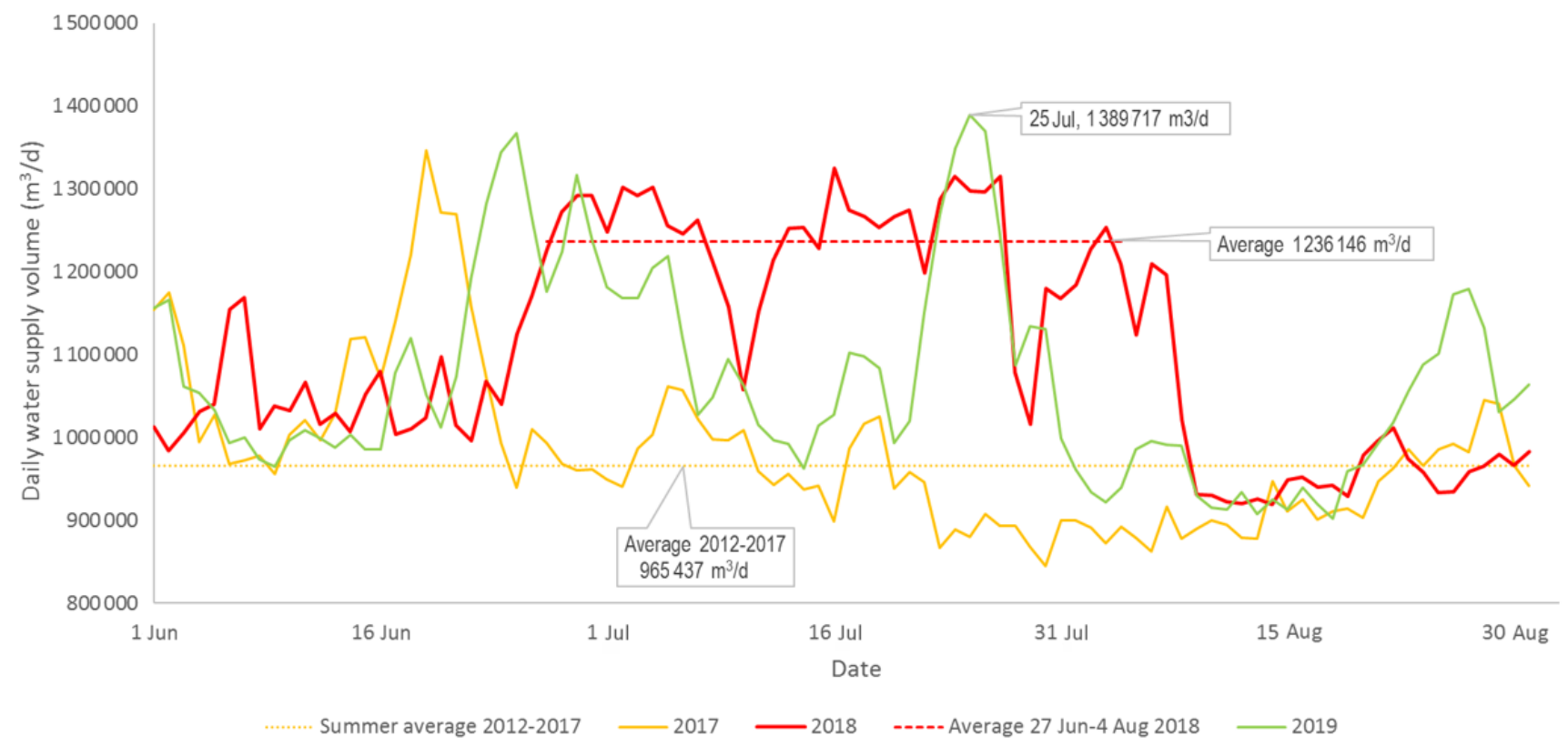

(b)

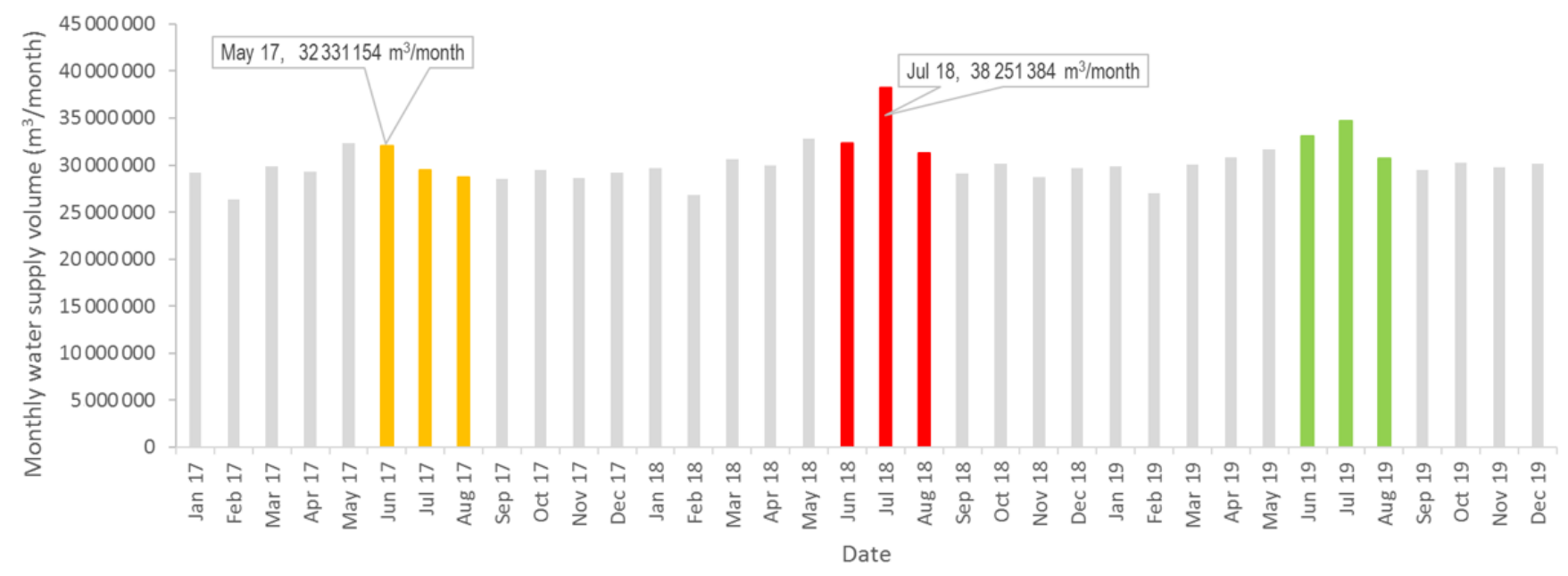

Figure 1. Daily (a) and monthly (b) drinking water supply volume by Dutch drinking water supplier Vitens during summer 2017 (average), 2018 (extreme), and 2019 (high) (Van Engelenburg et al., unpublished, 2020).

taminations may remain present for a long period of time, depending on the local hydrological characteristics (Jørgensen and Stockmarr, 2009; see Illustration case 2). The impact of contamination cannot be undone unless soil processes help to (partially) break down contaminants. Thorough monitoring for pollution is therefore essential for following groundwater quality trends and for responding adequately to these trends (Janža, 2015). Due to the expected deterioration of the raw water quality ${ }^{1}$, different and more complex treatment meth-

\footnotetext{
${ }^{1}$ Raw water is the (untreated) water that is treated to produce drinking water. This can be abstracted groundwater or surface water, depending on the available water resource.
}

ods are necessary to continuously meet the drinking water standards (Kools et al., 2019). In general, a more complex treatment method leads to higher energy use, use of additional excipients, water loss, and the production of waste materials, which will lead to a higher water tariff and to a higher environmental impact (Napoli and Garcia-Tellez, 2016). The results of the analysis are presented in Appendix B.

\section{Illustration case 2: groundwater quality development}

In the 1980s, the Dutch government implemented regulations to protect water quality by limiting the growing nitrate and phosphate surplus due to overuse of livestock manure. This 
resulted in a decrease in the nitrate surplus from 1985 on. However, due to the long travel times in groundwater, it took years before the impact of these regulations became visible in the groundwater quality. Figure 2 illustrates the period of time in which the nitrate concentration in an abstraction well still increased despite the 1985 regulations on reduction in the nitrate surplus at surface level. The nitrate concentration in this well increased until 2005 before the nitrate level started to decrease. Only since 2014 has the concentration dropped below the nitrate standard for groundwater of $50 \mathrm{mg} \mathrm{L}^{-1}$.

\subsection{Case 3: drinking water demand growth}

Due to drinking-water-saving strategies, the drinking water use in the Netherlands per person has decreased from 137 litre per person per day in 1992 to 119 litre per person per day in 2016 (Van Thiel, 2017). This development resulted in a decreasing total yearly drinking water demand volume in that same period, despite the population growth in the Netherlands (Baggelaar and Geudens, 2017). However, 2013 was a turning point at which the total yearly drinking water demand volume in the Netherlands started to grow again (Baggelaar and Geudens, 2017). The trend in the period 2013-2019 shows a strong increase in drinking water demand (see Illustration case 3). Delta scenarios have been developed for the Netherlands, projecting a drinking water demand development varying between a decrease of $10 \%$ to an increase of $35 \%$ in 2050 compared to 2015 (Wolters et al., 2018).

The drinking water demand growth rate for the period 2013-2019, as is seen within the Vitens supply area, compares to the growth rate in the maximum delta scenario of $35 \%$ growth from 2015 to 2050 (See Illustration case 3).

\section{Illustration case 3 : drinking water demand growth}

The increase in normalized drinking water supply volume as supplied by Vitens between 2015 and 2019 is $4.5 \%$ (Fig. 3). Due to this recent demand growth, the reserve capacity within the existing drinking water supply infrastructure is already limited. The drinking water demand growth rate for the period 2015-2019 compares to the growth rate in the maximum Delta scenario of $35 \%$ growth from 2015 to 2050 (Fig. 3). If this growth rate is not tempered through a significant reduction in the drinking water use, this would require a large extension of the drinking water supply infrastructure.

If this strong growth rate continues, it will put serious pressure on the drinking water supply. This will partially be due to limitations in the technical infrastructure but also partially due to limitations in the water resource availability caused by insufficient abstraction permits or a possibly negative impact on the hydrological system and stakeholders. Given the inflexibility of drinking water supply infrastructure to change, an integrated strategy is necessary to meet this uncertain development in the drinking water demand. To find sustainable solutions for the future, not only the technical infrastructure aspects must be solved. It also requires strategies on water saving, expansion of permits, development of new abstraction concepts using other water resources, as well as stakeholder processes in the design and use of the local drinking water supply system. This case is basically an extension of the first two cases in that the growing water demand amplifies the aspects caused by the drought in 2018 and the groundwater quality development. The results of the analysis of this case study are presented in Appendix C.

\section{Sustainability characteristics of drinking water supply}

In this section, the sustainability characteristics are presented, each elaborated further into five sustainability criteria. A detailed description of the resulting sustainability criteria can be found in Appendix E.

\subsection{Hydrological sustainability characteristics}

The following three hydrological sustainability characteristics are proposed that summarize the hydrological aspects affecting the drinking water supply as found in the case studies: water quality, water resource availability, and impact of drinking water abstraction (Table 1).

Water quality includes the monitoring and evaluation of current water quality and the trends and expected future development of the water quality and emerging contaminants, as described in the case of "groundwater quality development". In the WHO Guidelines for Drinking-water Quality (WHO, 2017), the importance of microbial aspects as a global water quality aspect with a health impact is additionally monitored, such as bacteriological contamination due to untreated wastewater or emergencies. The WHO Guidelines for Drinking-water Quality (WHO, 2017) also require monitoring of water quality aspects without a health impact, such as salinization, water hardness, and colour, which affect the acceptability of the drinking water (WHO and UNICEF, 2017).

Water resource availability for drinking water supply can be differentiated into the surface water and groundwater availability, as illustrated in case 1 - "2018 Summer drought". Other sustainability aspects are the vulnerability of the surface and/or groundwater system to the water quality being permanently affected by land use, as illustrated in the case of "groundwater quality development". The water resource availability can also be limited due to smallor large-scale emergencies caused by natural hazards, such as droughts, floods, earthquakes, or forest fires (WHO and UNICEF, 2017) that will put the sustainability of the local drinking water supply under pressure. 


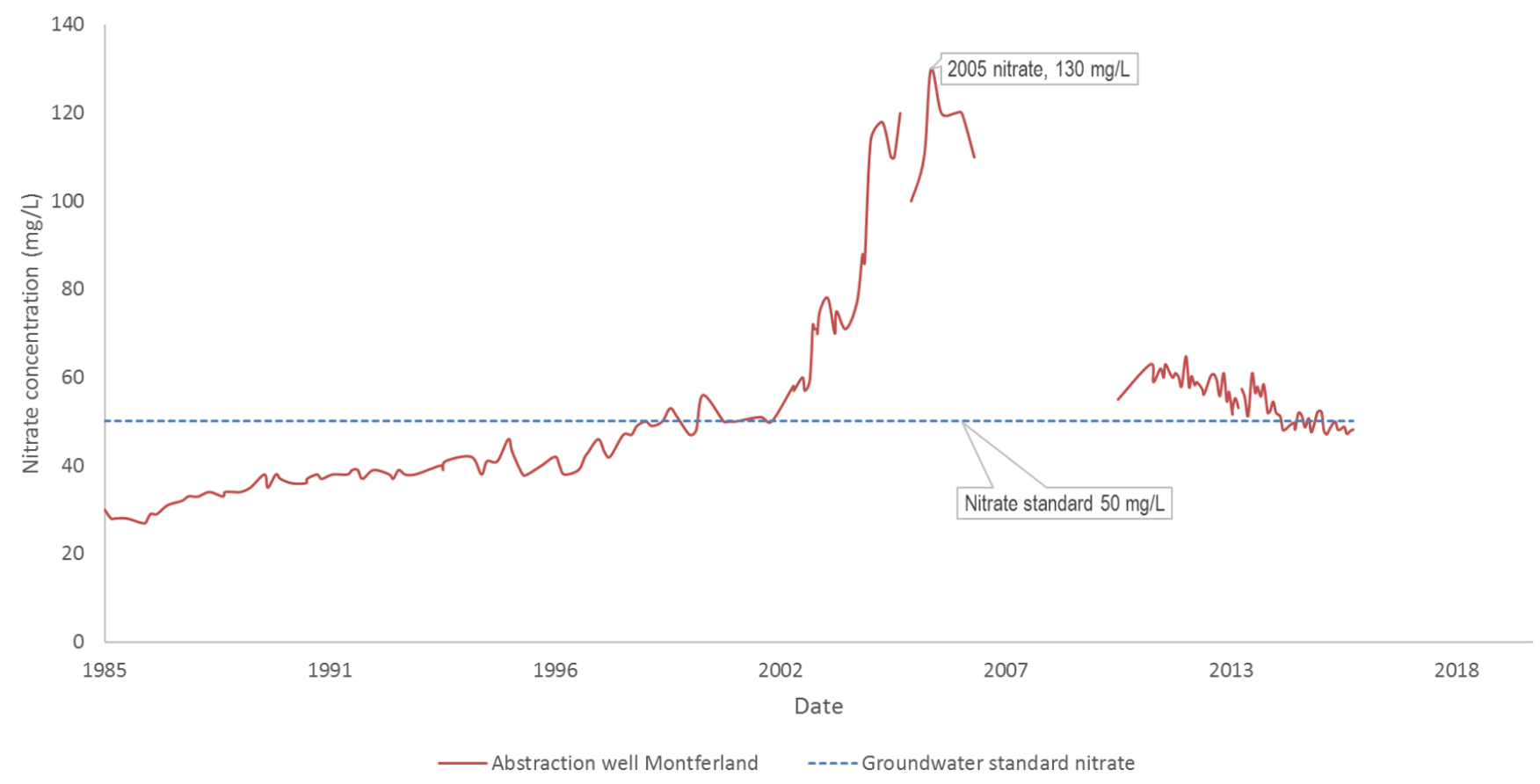

Figure 2. Development of nitrate in an abstraction well in Montferland (HEE-P07-07.0; coordinates - X213.540-Y434.761) in the province of Gelderland, the Netherlands (Van Engelenburg et al., unpublished, 2020), compared to the Dutch standard for nitrate concentration in groundwater $\left(50 \mathrm{mg} \mathrm{L}^{-1}\right)$.

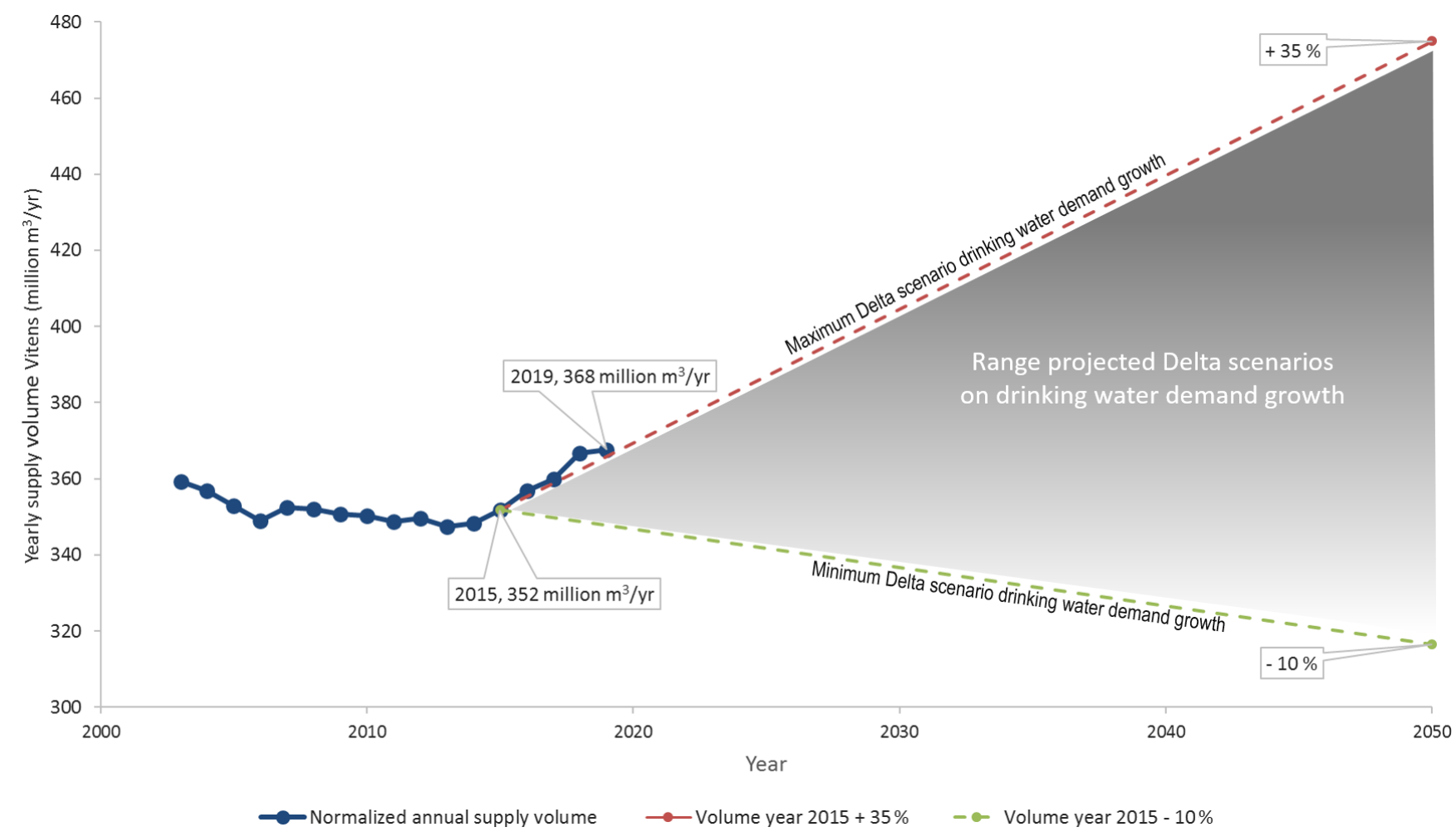

Figure 3. Development of the normalized annual drinking water volume supplied by Vitens (drinking water supplier), the Netherlands, 20032019 (Van Engelenburg et al., unpublished, 2020), compared to the projected Delta scenarios on drinking water demand growth (Wolters et al., 2018), ranging between a decrease of $10 \%$ and an increase of $35 \%$ in 2050 compared to 2015. The normalized annual drinking water supply volume excludes the impact of extreme weather conditions on the actual supplied annual volumes of drinking water. 
Table 1. Summary of proposed hydrological sustainability characteristics, hydrological aspects from case studies (see Appendices A-C), relevant SDG* indicators and WHO Guidelines for Drinking-water Quality (WHO, 2017) aspects, and hydrological sustainability criteria.

\begin{tabular}{|c|c|c|c|}
\hline $\begin{array}{l}\text { Hydrological sustainability } \\
\text { characteristics }\end{array}$ & Water quality & Water resource availability & $\begin{array}{l}\text { Impact of drinking water } \\
\text { abstraction }\end{array}$ \\
\hline $\begin{array}{l}\text { Sustainability aspects from case } \\
\text { studies }\end{array}$ & $\begin{array}{l}\text { Monitoring and evaluation } \\
\text { Sources of pollution } \\
\text { Contaminants } \\
\text { Emerging contaminants } \\
\text { Groundwater quality } \\
\text { Surface water quality } \\
\text { Raw water quality }\end{array}$ & $\begin{array}{l}\text { Other water resources } \\
\text { Surface water quantity } \\
\text { Groundwater quantity } \\
\text { Vulnerability of the water } \\
\text { system } \\
\text { Drought impact } \\
\text { Water discharge }\end{array}$ & $\begin{array}{l}\text { Impact of abstraction } \\
\text { Groundwater levels } \\
\text { Abstraction volume } \\
\text { Balance between annual } \\
\text { recharge and annual abstrac- } \\
\text { tion } \\
\text { Hydrological compensation }\end{array}$ \\
\hline SDG 6 targets* & $6.3 ; 6.5$ & $6.4 ; 6.5$ & $6.4 ; 6.6$ \\
\hline $\begin{array}{l}\text { WHO Guidelines for Drinking- } \\
\text { water Quality (WHO, 2017) }\end{array}$ & $\begin{array}{l}\text { Health risks from microbial } \\
\text { contamination } \\
\text { Acceptability of the drinking } \\
\text { water (salinization, hardness, } \\
\text { and colour) }\end{array}$ & $\begin{array}{l}\text { Small- or large-scale emergen- } \\
\text { cies caused by natural hazards } \\
\text { such as droughts, floods, earth- } \\
\text { quakes, or forest fires }\end{array}$ & - \\
\hline
\end{tabular}

* SDG -Sustainable Development Goal; see Appendix V for a summary of SDG 6 targets and indicators related to sustainability characteristics (UN, 2015).

The impact of the drinking water abstraction on the hydrological system entails the impact on both the surface water system and the groundwater system and also the balance between the annual drinking water abstraction volume and the annual recharge of the (local) water system. Whether the impact of the abstraction is or can possibly be hydrologically compensated is another sustainability aspect. The spatial impact of the local drinking water abstraction facility may also be a sustainability aspect because a drinking water facility requires a certain water storage area or reservoir, which might have a significant spatial impact in the area and, thus, might affect local stakeholders.

\subsection{Technical sustainability characteristics}

The following three technical sustainability characteristics are proposed that summarize the technical aspects for the drinking water supply as found in the case studies: reliability and resilience of the technical infrastructure and energy use and environmental impact of the drinking water supply (Table 2).

The reliability of the supply system is defined in this research as "the (un)likeliness of the technical system to fail" (Hashimoto et al., 1982). The current technical state of the drinking water production facility and the distribution infrastructure and the complexity of the water treatment are important technical sustainability criteria for the local drinking water supply system. Other technical criteria that should be considered are the supply continuity of the facility, which stands for the capability to meet the set legal standards for drinking water supply under all circumstances and the operational reliability to solve technical failures without any disturbance of the drinking water supply.

In this research, the resilience of the drinking water supply system is defined as "the possibility to respond to shortand long-term changes in water demand or water quality" (Hashimoto et al., 1982). Climate change and other developments in water demand and quality call for the use of more resilient technologies and processes and may require upgrades of water treatment and storage capacity (WHO and UNICEF, 2017). The cases of "2018 summer drought" and "drinking water demand growth" emphasize the importance of the available abstraction permits and the treatment and distribution capacity compared to the annual and peak water demand, respectively, for the resilience of the local drinking water supply system. Furthermore, the flexibility of the treatment method determines whether a drinking water supply system can deal with variation in, or deterioration of, wa- 
Table 2. Summary of proposed technical sustainability characteristics, technical aspects from case studies (see Appendices A-C), relevant SDG* indicators and WHO Guidelines for Drinking-water Quality (WHO, 2017) aspects, and technical sustainability criteria.

\begin{tabular}{|c|c|c|c|}
\hline $\begin{array}{l}\text { Technical sustainability } \\
\text { characteristics }\end{array}$ & $\begin{array}{l}\text { Reliability of technical } \\
\text { infrastructure }\end{array}$ & $\begin{array}{l}\text { Resilience of technical } \\
\text { infrastructure }\end{array}$ & $\begin{array}{l}\text { Energy use and environmental } \\
\text { impact }\end{array}$ \\
\hline $\begin{array}{l}\text { Sustainability aspects from case } \\
\text { studies }\end{array}$ & $\begin{array}{l}\text { Drinking water pressure } \\
\text { Drinking water treatment } \\
\text { Reliability of abstraction, treat- } \\
\text { ment, and distribution infras- } \\
\text { tructure }\end{array}$ & $\begin{array}{l}\text { Abstraction capacity } \\
\text { Treatment capacity } \\
\text { Treatment methods } \\
\text { Distribution capacity } \\
\text { Resilience of technical infras- } \\
\text { tructure }\end{array}$ & $\begin{array}{l}\text { Energy use } \\
\text { Environmental impact } \\
\text { Additional excipients } \\
\text { Wastewater } \\
\text { Waste materials }\end{array}$ \\
\hline SDG 6 targets* & $6.1 ; 6.4$ & $6.1 ; 6.4$ & 6.4 \\
\hline $\begin{array}{l}\text { WHO Guidelines for Drinking- } \\
\text { water Quality (WHO, 2017) }\end{array}$ & $\begin{array}{l}\text { Safely managed drinking water } \\
\text { services, i.e. improved drink- } \\
\text { ing water source on premises, } \\
\text { available when needed, and free } \\
\text { from contamination }\end{array}$ & $\begin{array}{l}\text { Resilient technologies and pro- } \\
\text { cesses } \\
\text { Upgrades of water treatment } \\
\text { and storage capacity }\end{array}$ & $\begin{array}{l}\text { Reliability of the energy supply } \\
\text { Renewability of the energy }\end{array}$ \\
\hline Sustainability criteria & $\begin{array}{l}\text { Technical state abstraction and } \\
\text { treatment facility } \\
\text { Technical state distribution } \\
\text { infrastructure } \\
\text { Complexity of water treatment } \\
\text { Supply continuity for } \\
\text { customers } \\
\text { Operational reliability }\end{array}$ & $\begin{array}{l}\text { Abstraction permit compared to } \\
\text { annual drinking water demand } \\
\text { Production capacity compared } \\
\text { to peak demand } \\
\text { Flexibility of treatment method } \\
\text { Technical innovations to } \\
\text { improve resilience } \\
\text { Technical investments to } \\
\text { improve resilience }\end{array}$ & $\begin{array}{l}\text { Energy use of abstraction and } \\
\text { treatment } \\
\text { Energy use of distribution } \\
\text { Environmental impact (addi- } \\
\text { tional excipients, wastewater, } \\
\text { and waste materials) } \\
\text { Reliability of the energy supply } \\
\text { Use of renewable energy }\end{array}$ \\
\hline
\end{tabular}

* SDG - Sustainable Development Goal; see Appendix V for a summary of SDG 6 targets and indicators related to sustainability characteristics (UN, 2015).

ter quality and emerging contaminants, which are the sustainability aspects found in the case of "groundwater quality development".

Energy use and environmental impact include the sustainability aspects from the cases of "groundwater quality development" and "drinking water demand growth". This entails the energy use of abstraction, treatment, and distribution and the environmental impact of additional excipients, wastewater, and other waste products of the treatment. Especially when the raw water quality deteriorates, the required water treatment methods become more complex. In general, this leads to large investments and an increased energy use and environmental impact, e.g. when advanced membrane filtration methods are required. Additional global sustainability aspects are the reliability of the energy supply and the renewability of the energy that is used (WHO, 2017).

\subsection{Socio-economic sustainability characteristics}

A total of three socio-economic sustainability characteristics are proposed that summarize the socio-economic aspects affecting the drinking water supply as found in the case studies, namely drinking water availability, water governance, and land and water use (Table 3).
The drinking water availability can be quantified by the percentage of households connected to the drinking water supply. A sustainable local drinking water supply provides sufficient drinking water of a quality that meets the national or international drinking water standards at a tariff that is affordable to all households (UN, 2015). In the Netherlands, by law the drinking water tariff must be built on a cost-recovery, transparent, and non-discriminatory basis (Dutch Government, 2009). Water-saving strategies will reduce the drinking water demand growth and, therefore, will contribute to the sustainability. Drinking water safety is a prerequisite for public health and sustainable drinking water supply. The WHO guidelines consider water safety plans essential for providing the basis for system protection and process control and for ensuring that water quality issues present a negligible risk to public health and that the drinking water is acceptable to consumers. Therefore, the WHO Guidelines for Drinking-water Quality (2017) monitor the availability of water safety plans, including emergency plans on how to act in case of drinking water supply disturbances, shortages, or drinking water quality emergencies (WHO and UNICEF, 2017). A water safety plan can be built on various safety protocols.

Water governance focuses on policies and legislation, enforcement, and compliance of regulations. Good governance also includes decision-making processes that consider differ- 
Table 3. Summary of proposed socio-economic sustainability characteristics, socio-economic aspects from case studies (see Appendices AC), relevant SDG* indicators and WHO Guidelines for Drinking-water Quality (WHO, 2017) aspects, and socio-economic sustainability criteria.

\begin{tabular}{|c|c|c|c|}
\hline $\begin{array}{l}\text { Socio-economic sustainability } \\
\text { characteristics }\end{array}$ & Drinking water availability & Water governance & Land and water use \\
\hline $\begin{array}{l}\text { Sustainability aspects from case } \\
\text { studies }\end{array}$ & $\begin{array}{l}\text { Customers } \\
\text { Drinking water availability } \\
\text { Drinking water demand } \\
\text { Drinking water tariff } \\
\text { Drinking water quality } \\
\text { Drinking water volume } \\
\text { Drinking water shortage } \\
\text { Emergencies and disturbances } \\
\text { Water saving }\end{array}$ & $\begin{array}{l}\text { Abstraction permits } \\
\text { Drinking water standards } \\
\text { Water authorities } \\
\text { Water legislation, policy, and } \\
\text { regulations } \\
\text { Drinking water suppliers } \\
\text { Compliance } \\
\text { Stakeholders }\end{array}$ & $\begin{array}{l}\text { Water use } \\
\text { Land use } \\
\text { Agriculture } \\
\text { Nature and groundwater- } \\
\text { dependent ecosystems } \\
\text { Financial compensation } \\
\text { Spatial impact }\end{array}$ \\
\hline SDG 6 targets* & 6.1 & $6.3 ; 6.4 ; 6.5 ; 6.6 ; 6 . a ; 6 . b$ & $6.3 ; 6.4$ \\
\hline $\begin{array}{l}\text { WHO Guidelines for Drinking- } \\
\text { water Quality (WHO, 2017) }\end{array}$ & Water safety plan & $\begin{array}{l}\text { Small- or large-scale emergen- } \\
\text { cies for the drinking water sup- } \\
\text { ply caused by human activities } \\
\text { or conflicts }\end{array}$ & - \\
\hline Sustainability criteria & $\begin{array}{l}\text { Percentage of connected house- } \\
\text { holds } \\
\text { Drinking water service quality } \\
\text { Drinking water tariff } \\
\text { Water-saving strategy } \\
\text { Water safety protocols }\end{array}$ & $\begin{array}{l}\text { Availability of (drinking) water } \\
\text { legislation and policies } \\
\text { Compliance of drinking water } \\
\text { supplier } \\
\text { Decision-making process by } \\
\text { (local) authorities } \\
\text { Local stakeholder interests } \\
\text { Emergency risk caused by } \\
\text { human activities or conflicts }\end{array}$ & $\begin{array}{l}\text { Land use (including subsurface } \\
\text { use) } \\
\text { Water use for purposes other } \\
\text { than drinking water } \\
\text { Regulations on land and water } \\
\text { use } \\
\text { Limitations on land or water } \\
\text { use } \\
\text { Financial compensation for } \\
\text { economic damage from the } \\
\text { impact of abstraction or } \\
\text { limitations on land use }\end{array}$ \\
\hline
\end{tabular}

* SDG - Sustainable Development Goal; see Appendix V for a summary of SDG 6 targets and indicators related to sustainability characteristics (UN, 2015).

ent stakeholder interests to ensure accountable, transparent, and participatory governance (UNESCAP, 2009). The availability of (inter-) national and local policies and legislation on drinking water supply as well as on water management, including regulations and permits, and the level of compliance of the drinking water supplier to these policies and legislation, is important for socio-economic sustainability. The sustainability of the local drinking water supply is also characterized by the stakeholders' interests related to the presence of a local drinking water abstraction and by how local authorities weigh these interests in their decision-making processes. A final aspect in water governance that reaches further than local stakeholder interests is the risk of small- or large-scale emergencies for the drinking water supply caused by human activities or conflicts (WHO and UNICEF, 2017).

The local land and water use, at surface and subsurface level, affects the water quality and quantity. It may have resulted in historical contaminant sources, causing point or non-point water pollution, but it may also lead to emerging contaminants that provide new risks to water quality. Addi- tionally, water use for other purposes may limit the availability of water resources for drinking water. Regulations to protect water quality or water quantity may cause limitations on local land and water use. Financial compensation for suffered economic damage due to the impact of the abstraction or the limitations caused by protection regulations can be an important aspect for the sustainability of the drinking water supply system.

\section{Discussion}

\subsection{Use of DPSIR systems approach}

In this study, we used an integrated systems approach to analyse the local drinking water supply system, combining hydrological, technical, and socio-economic aspects of the system. The analysis of the three selected cases with DPSIR supported the identification of the aspects that shape the sustainability of the local drinking water supply system. The case analysis did indeed help to account for differences between 
short-term and long-term developments and for the impact of external influences that come from the national and international scale.

The applied DPSIR approach is a linear socio-ecological framework originally developed to identify the impact of human activities on the state of the environmental system (Binder et al., 2013). However, the local drinking water supply system is a complex rather than linear system because the impact of pressure on one system element could lead to pressure on another system element. This complicated the identification of pressures and impacts. For instance, high temperatures and lack of precipitation caused a higher drinking water demand and surface water quality deterioration. Both consequently presented pressures with an impact on the resilience and reliability of the technical drinking water supply infrastructure. Although this hampered the analysis, the use of DPSIR supported a systematic analysis of the local drinking water supply cases and helped to identify the sustainability aspects. Use of a different integrated systems approach would not have led to a significantly different outcome for the case analysis. A next step could potentially be to use the identified system characteristics for system dynamics analysis and modelling. However, this is beyond the scope of this current research.

\subsection{General applicability of the sustainability characteristics}

To increase the general applicability of the results from the analysis of the Dutch cases on drinking water supply, the identified sustainability aspects were related to worldwide acknowledged sustainability aspects by cross-checking with international policies on drinking water supply. This put the aspects in a broader perspective, which may contribute to the transferability of the proposed sustainability characteristics and criteria to other areas.

Assessments to understand the sustainability challenges and the impact of future developments and adaptation options are seen as powerful tools for policy-making (Ness et al., 2007; Singh et al., 2012). The sustainability characteristics, as proposed in this research, may be used to develop a sustainability assessment for the local drinking water supply system that can help to identify sustainability challenges and trade-offs of adaptation strategies. Trade-off analysis supports decision-making processes and makes these processes more transparent to local stakeholders (Hellegers and Leflaive, 2015). Based on the local situation and data availability, adequate indicators and indices can be selected to quantify the sustainability characteristics in a certain area (Van Engelenburg et al., 2019).

\section{Conclusions}

The aim of this study was to identify a set of characteristics that describe the sustainability of a local drinking water supply system in the Netherlands to support policy- and decision-making on sustainable drinking water supply. The use of the DPSIR systems approach was an adequate method for the analysis of the cases. The results of the analysis of the three cases confirmed the hypothesis that sustainability is contextual, resulting in different sustainability aspects in the various cases. The combined results of the analysis of three different practice cases contributed to a better understanding of drinking water supply in the Netherlands. Crosschecking of the results of case analysis with international policies on drinking water supply provided a wider context than the Netherlands and has thus contributed to the general applicability of the identified sustainability characteristics.

Based on the presented analysis, the following set of hydrological, technical, and socio-economic sustainability characteristics is proposed, respectively: (1) water quality, water resource availability, and impact of drinking water abstraction; (2) reliability and resilience of the technical system and energy use and environmental impact; (3) drinking water availability, water governance, and land and water use. An elaboration of the sustainability characteristics into more detailed criteria may further increase the value of the results of this research in the process of the development of policies on sustainable drinking water supply in the Netherlands. 
Appendix A: Results of analysis case 1: 2018 summer drought

Table A1. Summary of the impact, short- and long-term response, and sustainability aspects in case $1-2018$ summer drought. In the subsequent Table A2, the full results of the case study are presented.

\begin{tabular}{llll}
\hline Impact & Short-term response & Long-term response & Sustainability aspects \\
\hline $\begin{array}{l}\text { Extreme drinking water use; } \\
\text { high drinking water demand. }\end{array}$ & $\begin{array}{l}\text { Drinking water suppliers' in- } \\
\text { creased abstraction volume. }\end{array}$ & $\begin{array}{l}\text { Development of water-saving } \\
\text { strategies. }\end{array}$ & $\begin{array}{l}\text { Drinking water use, drinking } \\
\text { water demand, drinking water } \\
\text { suppliers, abstraction volumes, } \\
\text { and water saving. }\end{array}$
\end{tabular}

Drought, falling water dis- Water use limitations, water aucharges and groundwater levels, thorities apply existing drought and damage to groundwaterdependent ecosystems and agriculture.
Development of additional water shortage policy for water management and water gover- $\begin{aligned} & \text { water policy, and risks for water manage } \\ & \text { quality. }\end{aligned}$
nance.

Drought, water discharge, groundwater levels, groundwater-dependent ecosystems, agriculture, water use, water authorities, water policy, water management, water governance, and water availability.

\section{Customers worried about drink- ing water availability. \\ Declining surface water dis- charge and quality. \\ Drinking water suppliers called on customers to save drinking water. \\ Drinking water suppliers took measures to safeguard raw wa- ter quality.}

Societal support for drinkingwater-saving strategies.

Development of additional policies on water quality protection.

Customers, drinking water availability, drinking water suppliers, and water saving.

Surface water discharge, surface water quality, drinking water suppliers, raw water quality, water management policies, and water use.

Groundwater quality deteriora- $\quad$ No response possible due to a Development of additional polition. lack of water.

Groundwater quality, surface water quality, water shortage, surface water discharge, and water management policies

Drinking water quality, treatment method, and distribution infrastructure. of distribution pipelines to limit risk of temperature rise.

Drinking water demand, abstraction volume, impact of abstraction, land use, stakeholders, agriculture, nature, and drinking water suppliers.

Drinking water demand, abstraction volume, abstraction capacity, abstraction permit, resilience of abstraction, legal authorities, water regulations, water legislation, and saving drinking water.

Shortage of drinking water dur- Reduced drinking water supply ing peak demand due to insufficient resilience of treatment infrastructure. volume.

Adjustment of resilience and reliability of treatment infrastructure.
Treatment volume, treatment capacity, drinking water shortage, reliability of the treatment, resilience of the treatment, drinking water standards, drinking water demand, and drinking water suppliers. 
Table A1. Continued.

\begin{tabular}{|c|c|c|c|}
\hline Impact & Short-term response & Long-term response & Sustainability aspects \\
\hline $\begin{array}{l}\text { High energy use and envi- } \\
\text { ronmental impact of extreme } \\
\text { drinking water production. }\end{array}$ & - & $\begin{array}{l}\text { Incorporating impact to energy } \\
\text { use and environmental impact } \\
\text { in the design of measures to } \\
\text { improve the resilience and re- } \\
\text { liability of technical infrastruc- } \\
\text { ture. }\end{array}$ & $\begin{array}{l}\text { Drinking water demand, energy } \\
\text { use, environmental impact, and } \\
\text { drinking water suppliers. }\end{array}$ \\
\hline
\end{tabular}




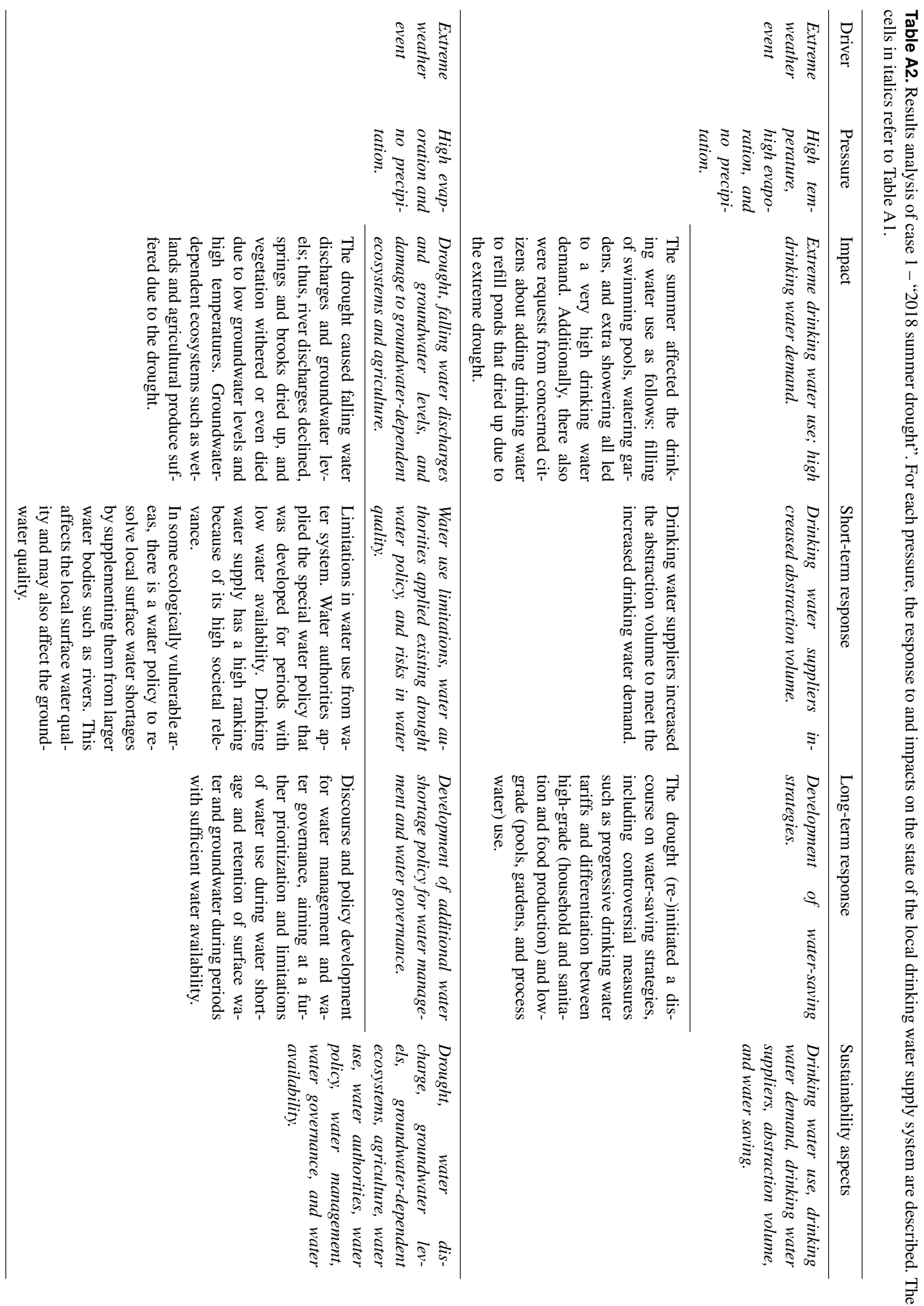




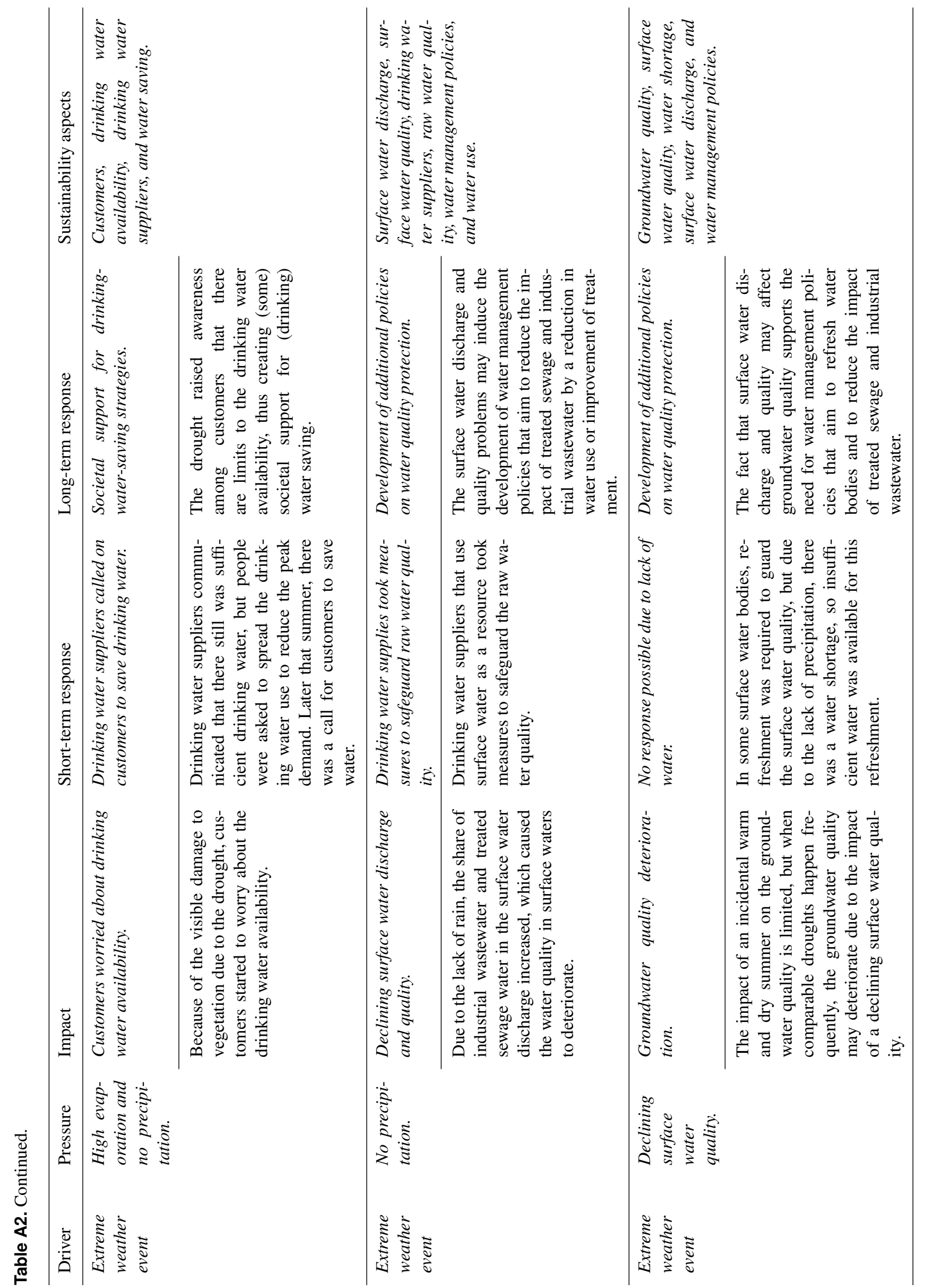




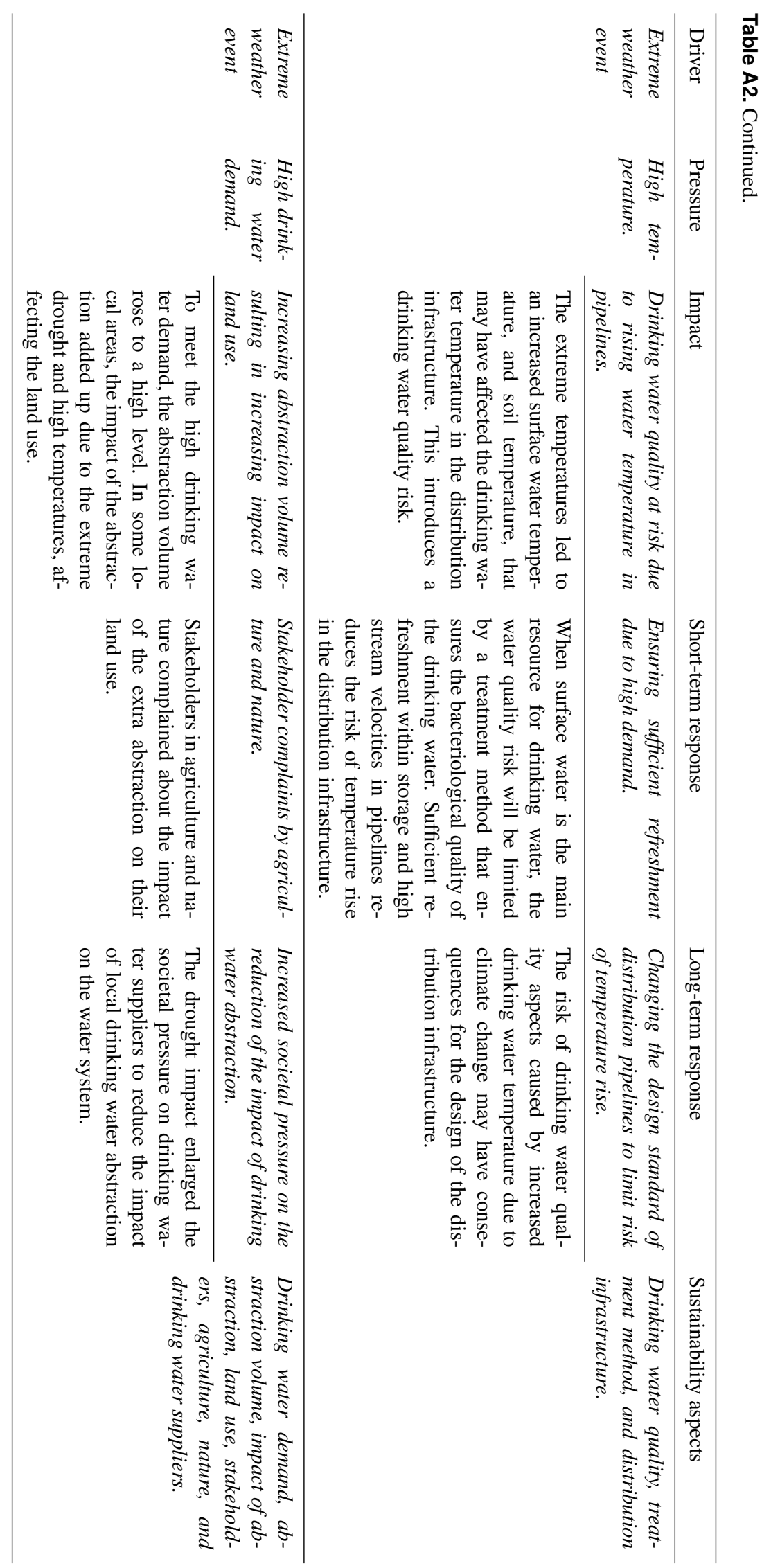




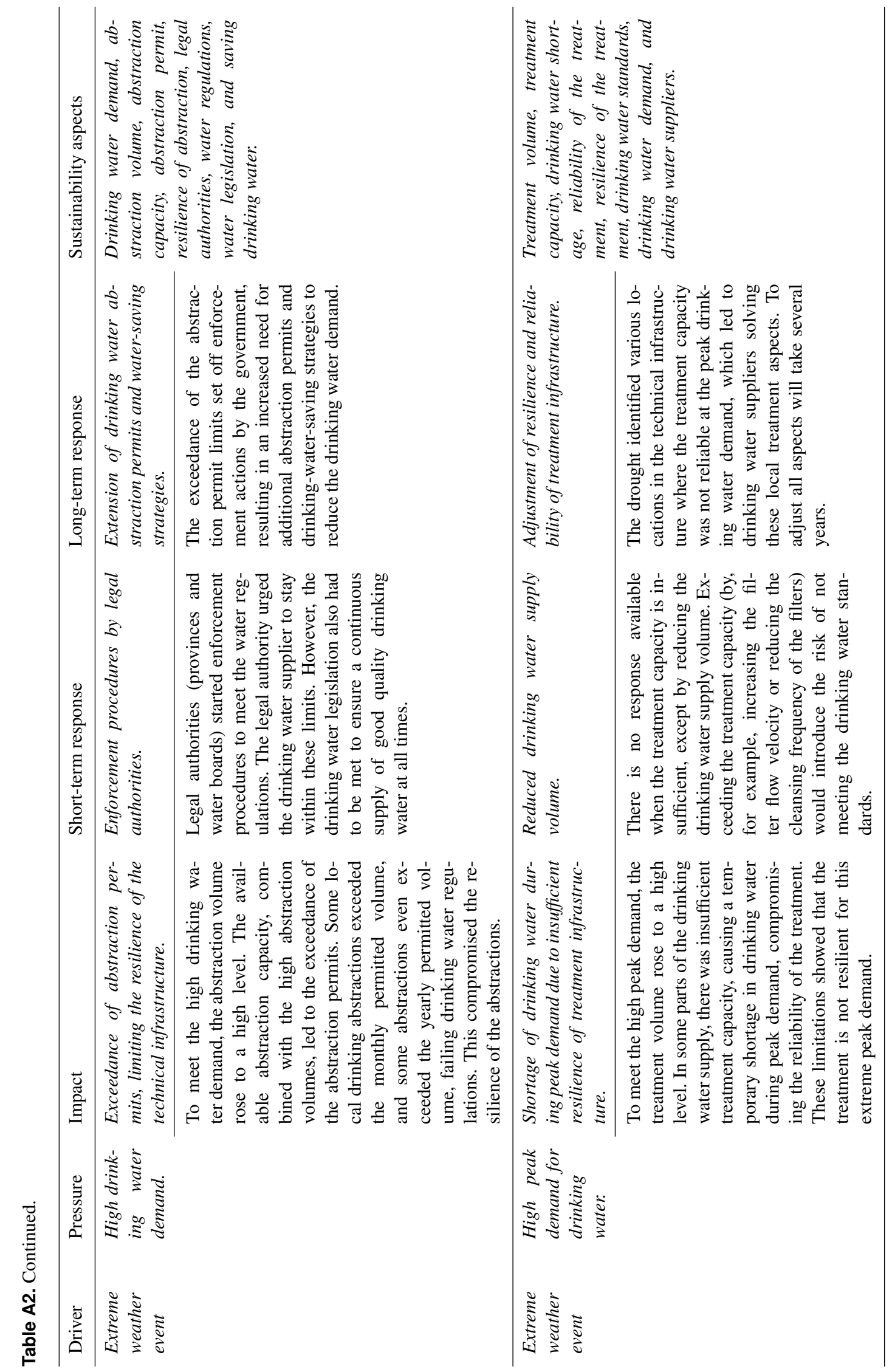




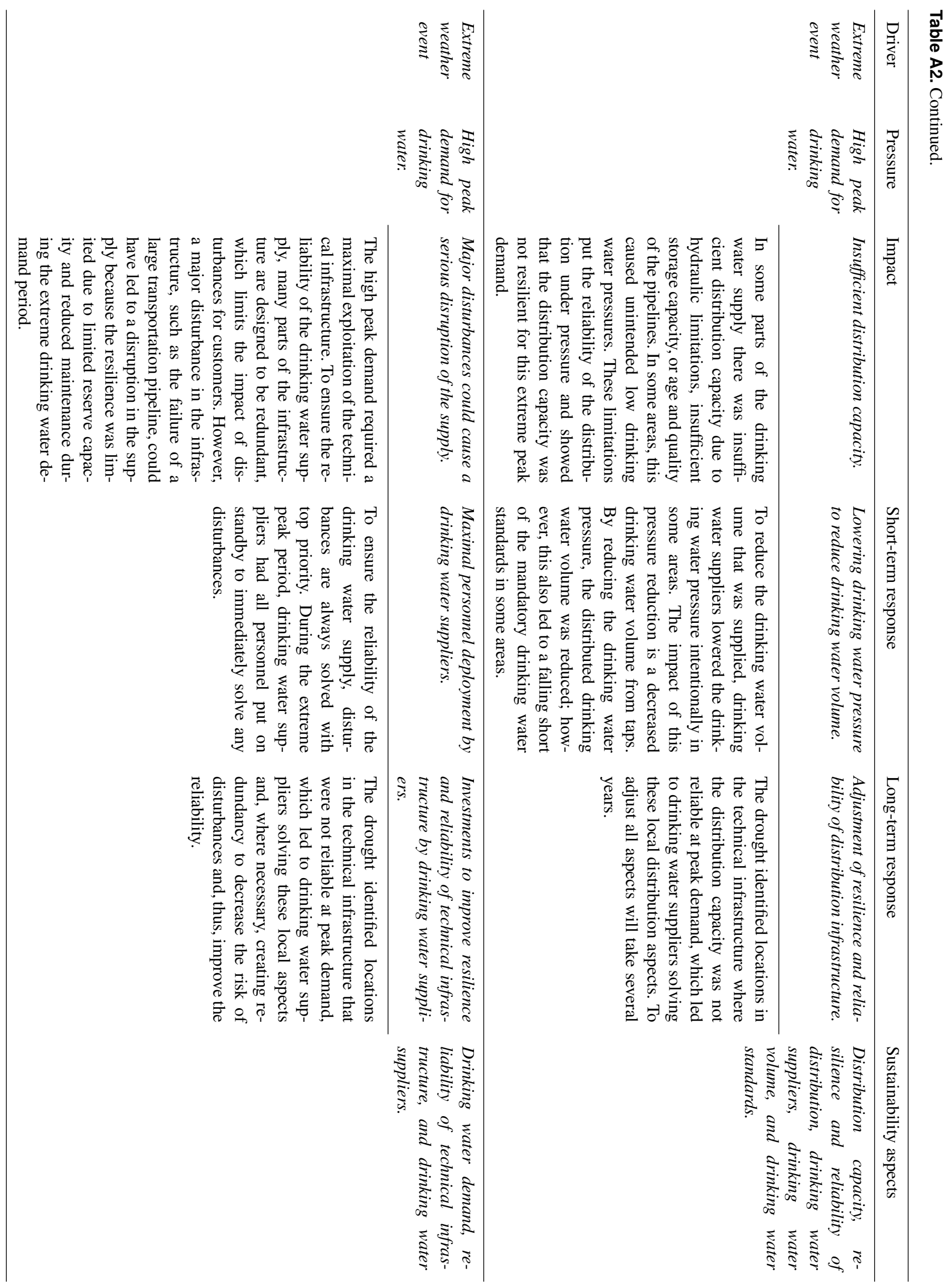




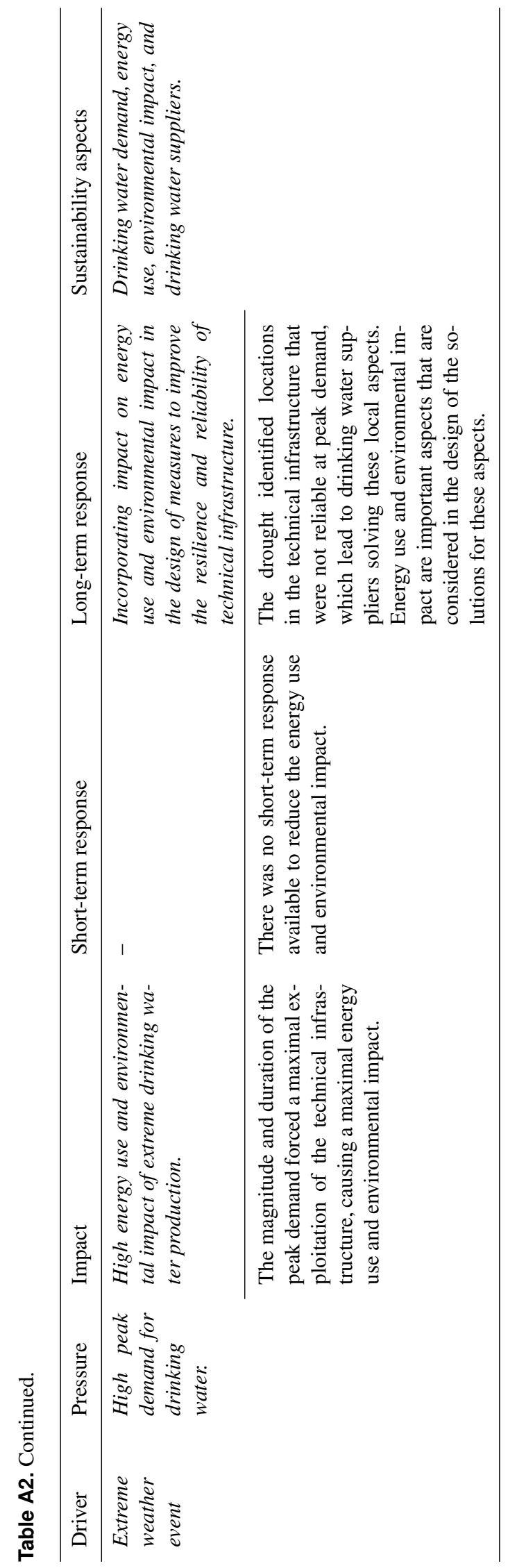


Appendix B: Results of analysis case 2: groundwater quality development

Table B1. Summary of the impact, short- and long-term response, and sustainability aspects in case 2 - groundwater quality development (for complete results of the case study, see Table B2).

\begin{tabular}{llll}
\hline Impact & Short-term response & Long-term response & Sustainability aspects \\
\hline $\begin{array}{l}\text { Surface water quality deterio- } \\
\text { rates due to limited surface wa- } \\
\text { ter discharge. }\end{array}$ & $\begin{array}{l}\text { Monitoring and evaluation of } \\
\text { water quality development. }\end{array}$ & $\begin{array}{l}\text { Water legislation on water } \\
\text { quality and quantity protection } \\
\text { and drinking-water-saving water discharge, monitoring } \\
\text { strategies. }\end{array}$ & $\begin{array}{l}\text { and evaluation, water legisla- } \\
\text { tion, water quality and quantity, } \\
\text { and saving drinking water. }\end{array}$ \\
\hline
\end{tabular}

Groundwater quality deteriorates due to deteriorating surface water quality.

Soil energy systems may affect groundwater quality.
Monitoring and evaluation of water quality development.

Monitoring and evaluation of water quality development and research.
Improvement of sewage and wastewater treatment, and water-saving strategies.

Groundwater protection regulations.

Groundwater quality, surface water quality, monitoring and evaluation, and water saving.

Groundwater quality, groundwater pollution, research, monitoring and evaluation, regulations, and groundwater quality protection.

Local and upstream land and water use affects the surface water quality.
Monitoring and evaluation of water quality development.
Policy and measures to meet water legislation to protect and improve water quality and quantity.

Surface water quality, land and water use, contaminants, monitoring and evaluation, water legislation, and water quantity.

Diffuse and point sources of pollution affect surface water

Monitoring and evaluation of water quality development.
Measures to remove historical sources of pollution and to prevent new sources of pollution.

Groundwater quality, nutrients, organic micro-pollutants, other contaminants, surface water quality, monitoring and evaluation, water legislation, and water quality protection.

Emerging contaminants in surface and groundwater require new drinking water treatment methods.
Enforcement of groundwater protection regulations on pollution incidents and monitoring and evaluation.
Development of treatment methods to remove emerging contaminants from sewage, industrial wastewater, and/or drinking water.
Emerging contaminants, groundwater quality, surface water quality, resilience and reliability of the drinking water treatment, groundwater protection, land and water use, water legislation, sources of pollution, drinking water treatment methods, energy use, environmental impact, and drinking water tariff.

Land use change, groundwater quality, sources of pollution, groundwater protection regulations, water use, enforcement of regulations, monitoring and evaluation, drinking water abstraction, extensive land use, nature, agriculture, and water system. 
Table B1. Continued.

\begin{tabular}{|c|c|c|c|}
\hline Impact & Short-term response & Long-term response & Sustainability aspects \\
\hline $\begin{array}{l}\text { Surface water and groundwa- } \\
\text { ter quality deterioration deter- } \\
\text { mine the required drinking wa- } \\
\text { ter treatment. }\end{array}$ & $\begin{array}{l}\text { Monitoring of drinking water } \\
\text { quality; in case of emergencies, } \\
\text { measures are taken to safeguard } \\
\text { the drinking water quality. }\end{array}$ & $\begin{array}{l}\text { Adjustment of treatment meth- } \\
\text { ods to be able to continue to } \\
\text { meet the drinking water stan- } \\
\text { dards. }\end{array}$ & $\begin{array}{l}\text { Raw water quality, drinking wa- } \\
\text { ter standards, water quality, vul- } \\
\text { nerability of the water sys- } \\
\text { tem for contamination, treat- } \\
\text { ment methods, reliability and } \\
\text { resilience of treatment, drink- } \\
\text { ing water quality, emergencies, } \\
\text { energy use, environmental im- } \\
\text { pact, and drinking water tariff. }\end{array}$ \\
\hline $\begin{array}{l}\text { Variations in raw water qual- } \\
\text { ity can only be handled if the } \\
\text { treatment method is resilient to } \\
\text { these variations. }\end{array}$ & $\begin{array}{l}\text { Monitoring and evaluation of } \\
\text { water quality development. }\end{array}$ & $\begin{array}{l}\text { Increase in resilience and reli- } \\
\text { ability of drinking water treat- } \\
\text { ment. }\end{array}$ & $\begin{array}{l}\text { Surface water quality, ground- } \\
\text { water quality, resilience and re- } \\
\text { liability of the treatment, moni- } \\
\text { toring and evaluation, raw wa- } \\
\text { ter quality, energy use, envi- } \\
\text { ronmental impact, and drinking } \\
\text { water tariff. }\end{array}$ \\
\hline
\end{tabular}




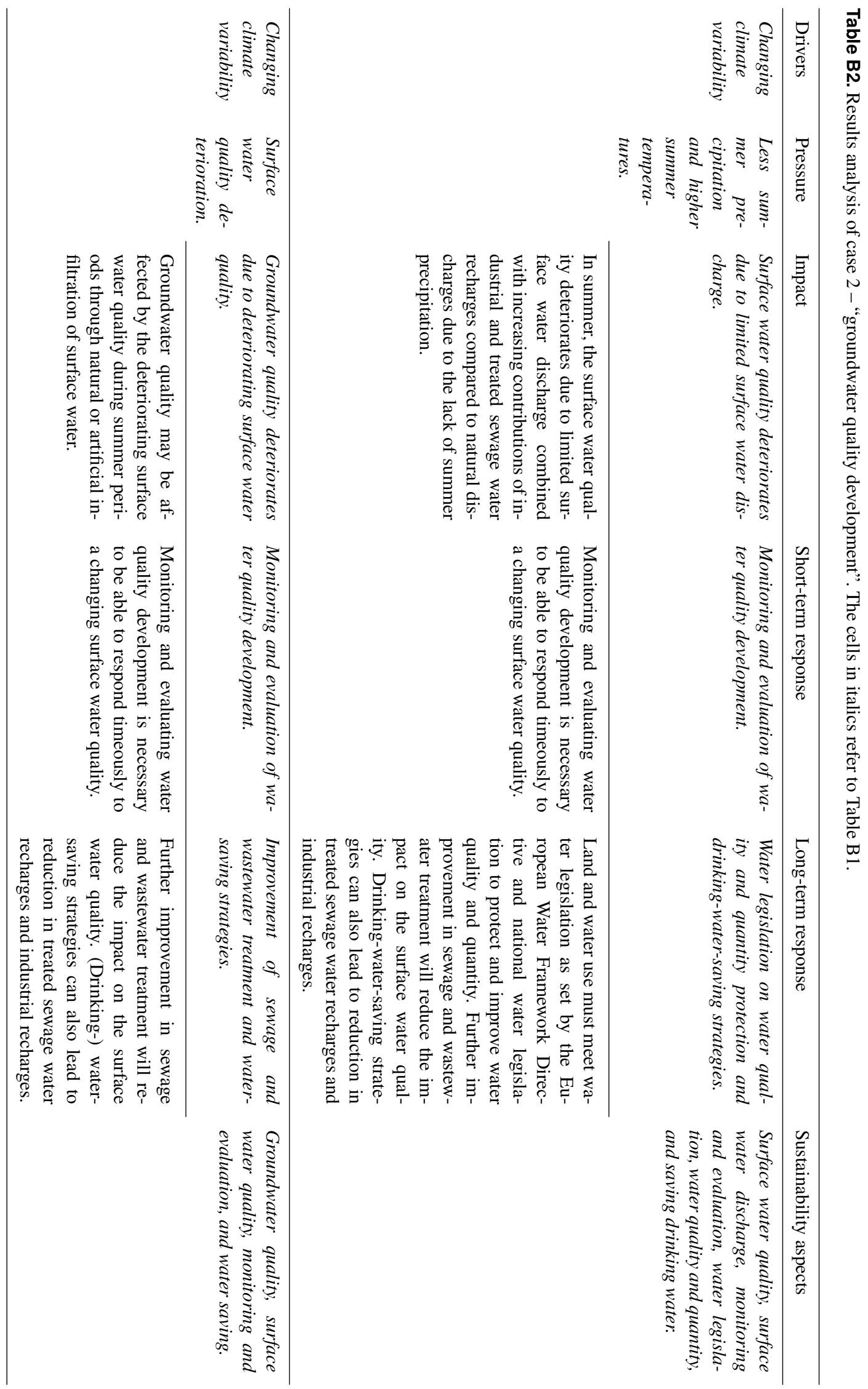




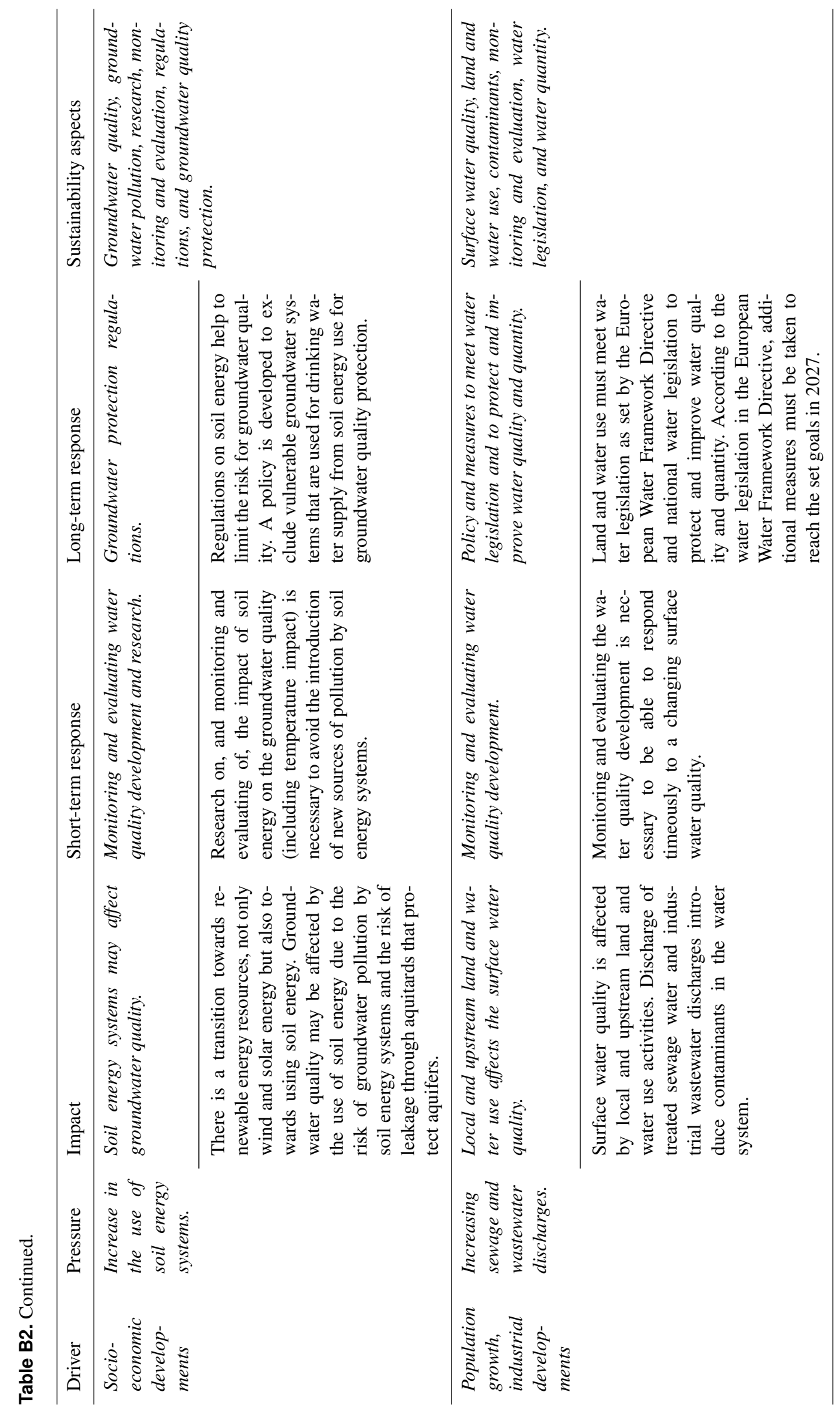



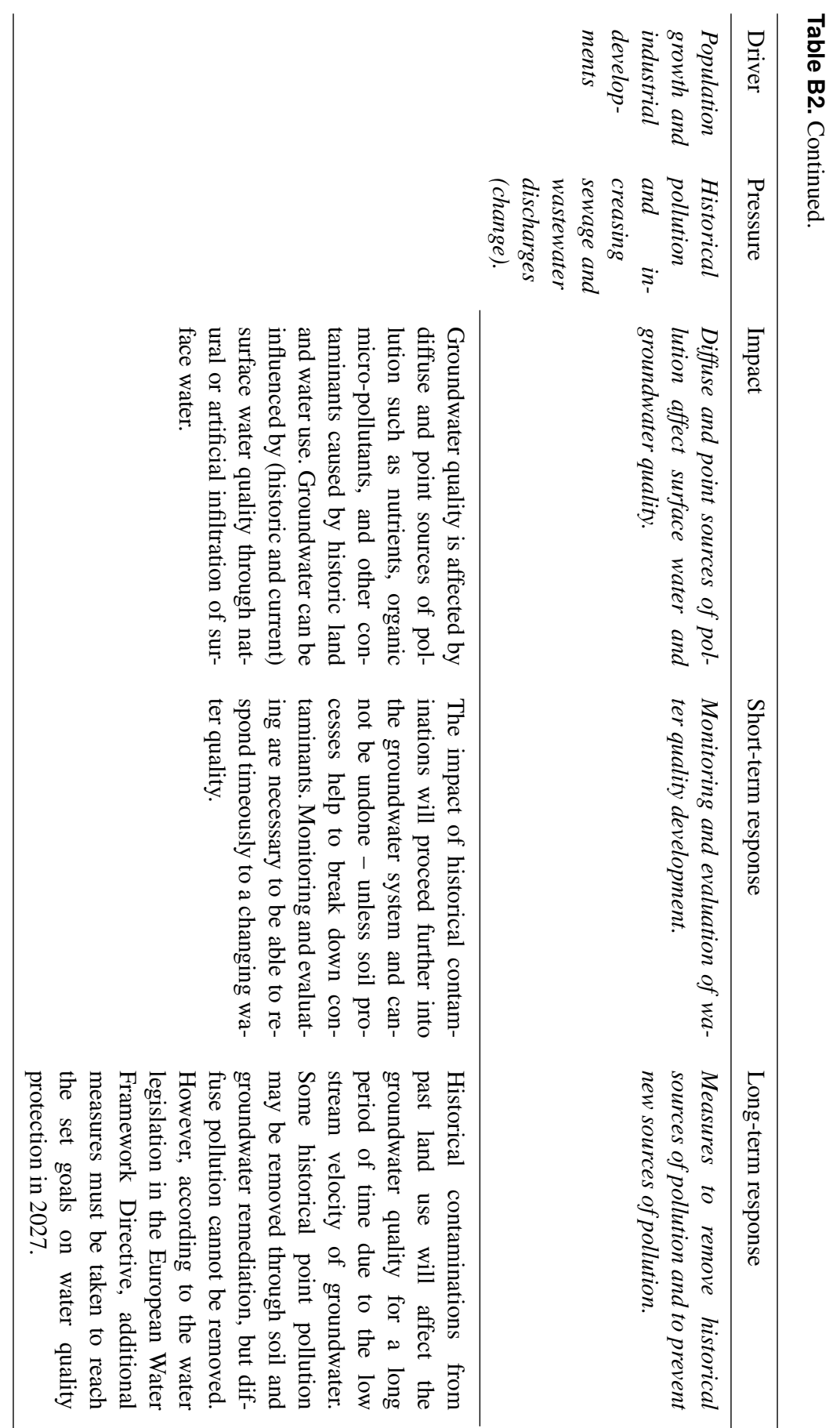


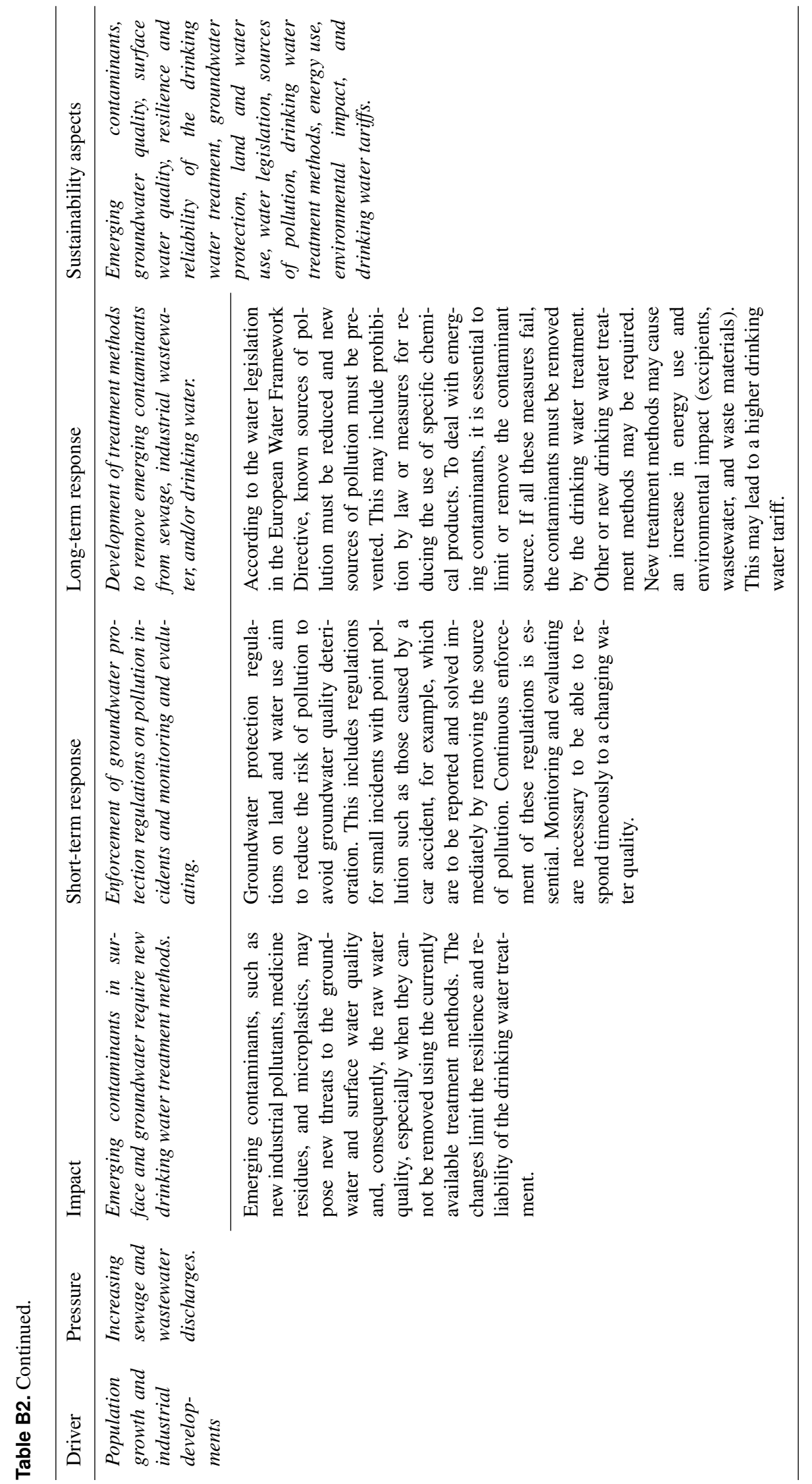




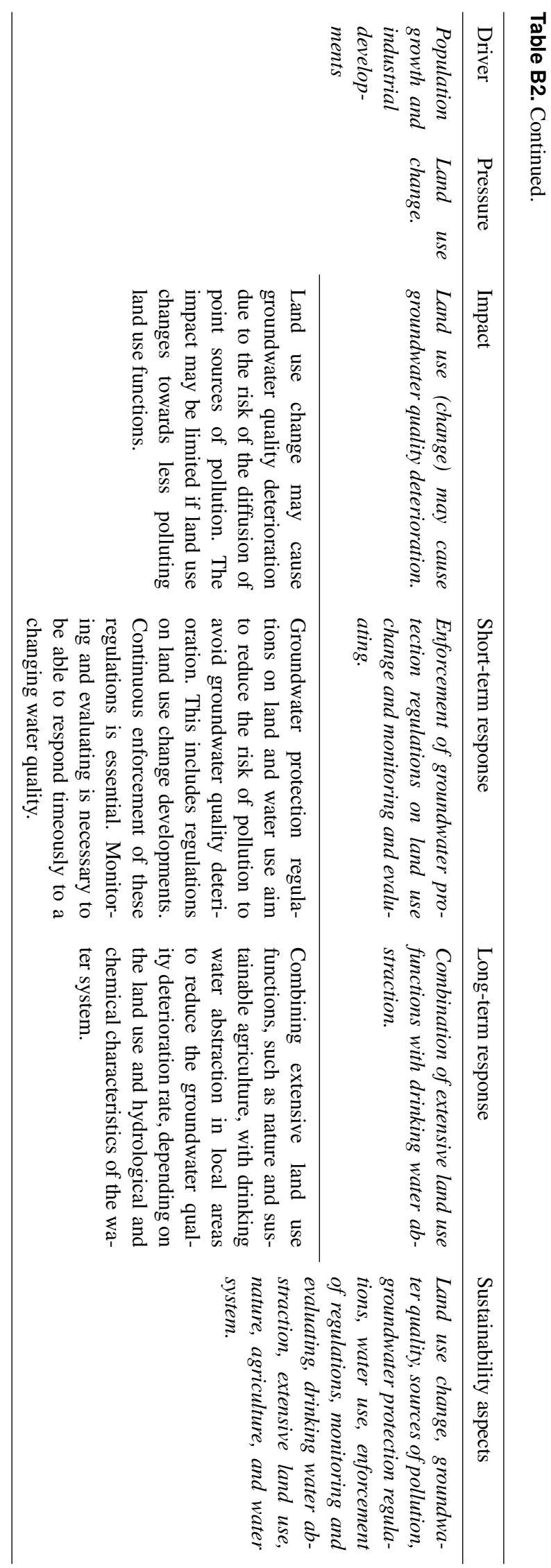




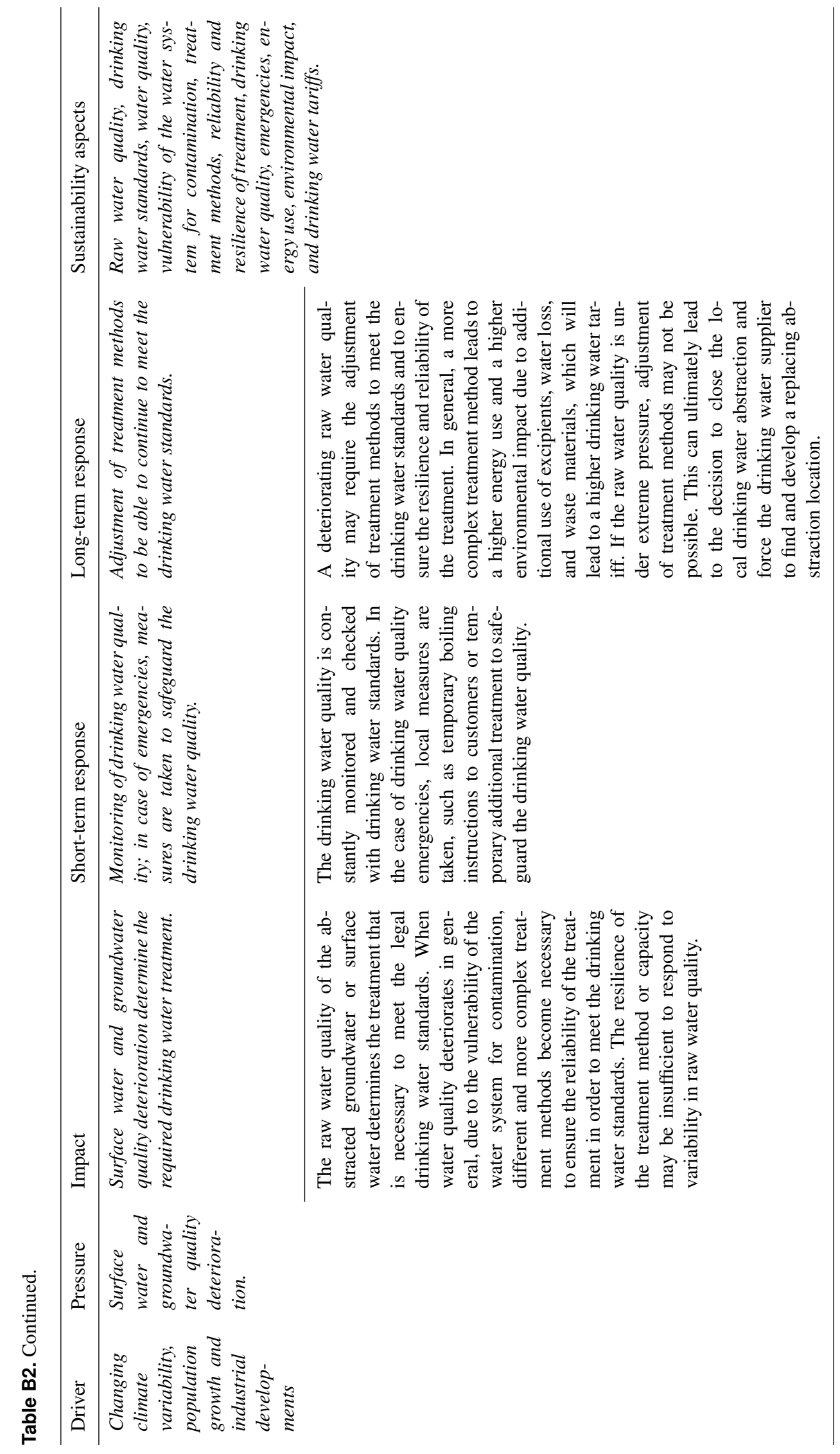




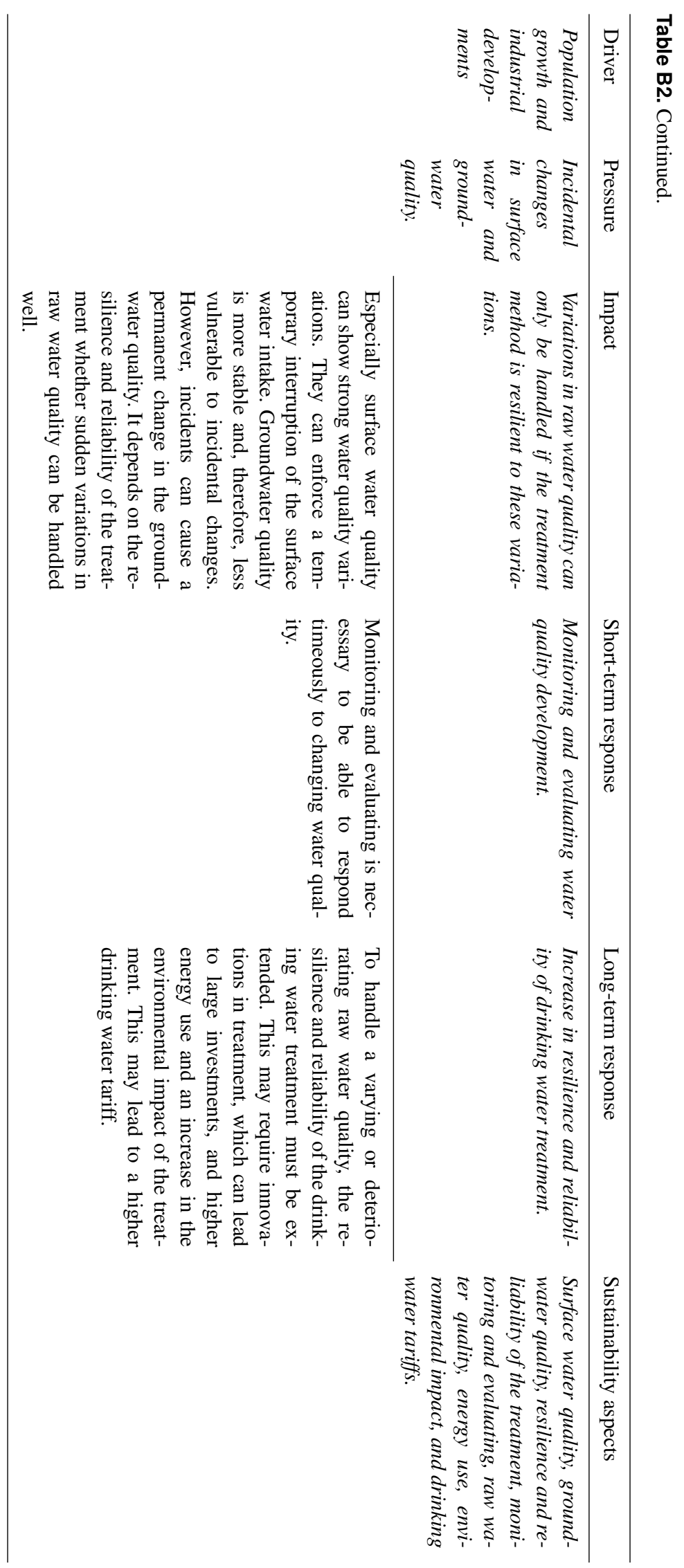




\section{Appendix C: Results of analysis case 3: drinking water demand growth}

Table C1. Summary of the impact, short- and long-term response, and sustainability aspects in case 3 - drinking water demand growth (for complete results of the case study, see Table $\mathrm{C} 2$ ).

\begin{tabular}{llll}
\hline Impact & Short-term response & Long-term response & Sustainability aspects \\
\hline $\begin{array}{l}\text { A limited water resource avail- } \\
\text { ability will affect the drinking }\end{array}$ & See Table A2. & See Table A2. & Water resource availability, \\
water availability. & & & $\begin{array}{l}\text { drinking water availability, } \\
\text { resilience of drinking water } \\
\text { supply, drinking water demand, } \\
\text { and water legislation. }\end{array}$
\end{tabular}

A water quality deterioration affects the resilience and reliability of the drinking water treatment.

A growing drinking water demand will put the reliability and resilience of the technical infrastructure under pressure.
See Table B2

See Table A2.

A declining drinking water demand may also put the resilience of the technical infrastructure under pressure. of a decline in drinking water demand.
See Table B2.

Water quality, drinking water treatment, reliability of treatment, and drinking water standards.

Drinking water demand, reliability of technical infrastructure, drinking water suppliers, drinking water availability, treatment, energy use, environmental impact, and drinking water tariff. extension of the technical in frastructure.

Adaptation strategies that increase the resilience of the infrastructure to growth and a decline in the drinking water demand.
Drinking water demand, reliability, and resilience of technical infrastructure. 


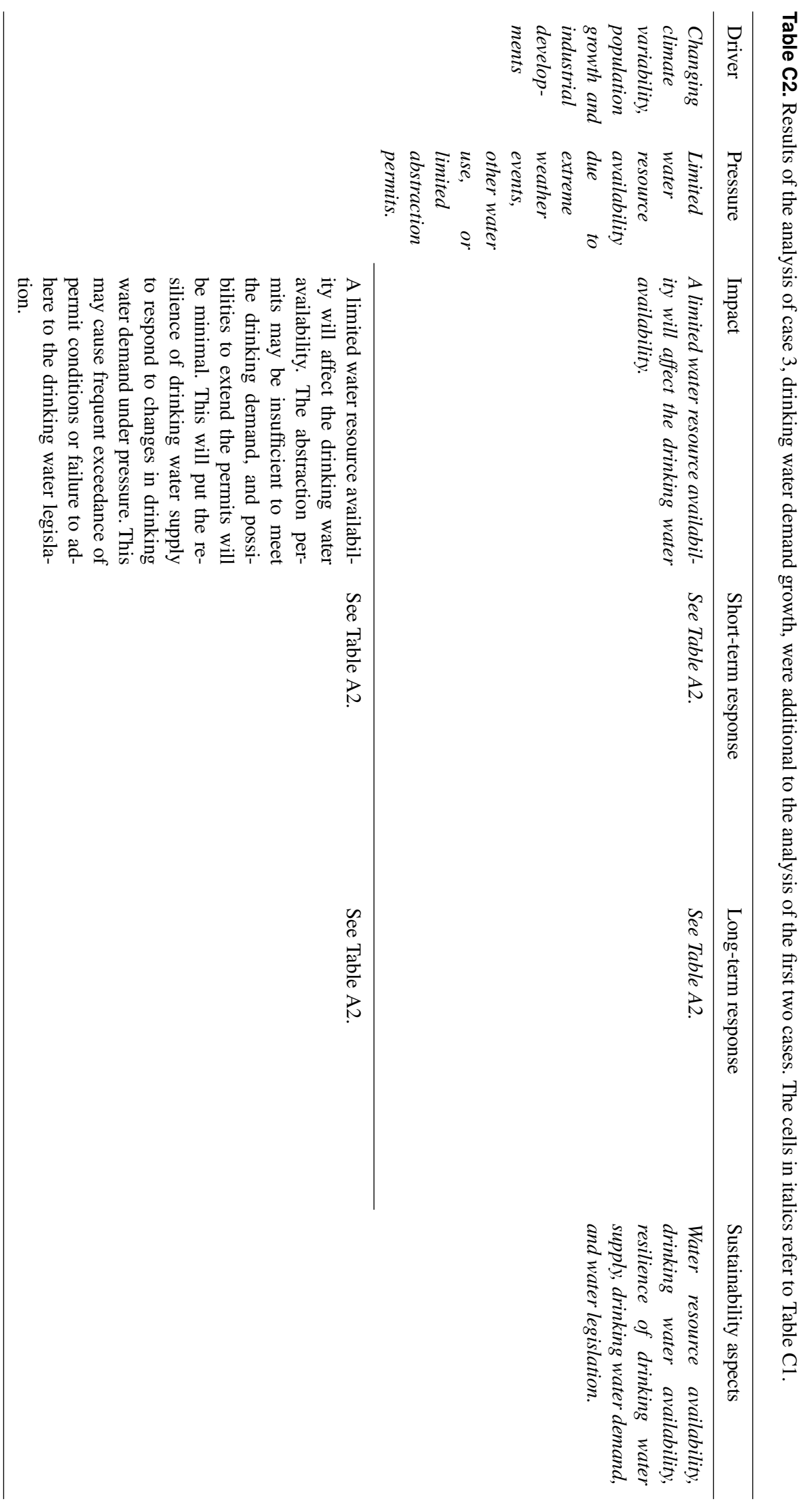




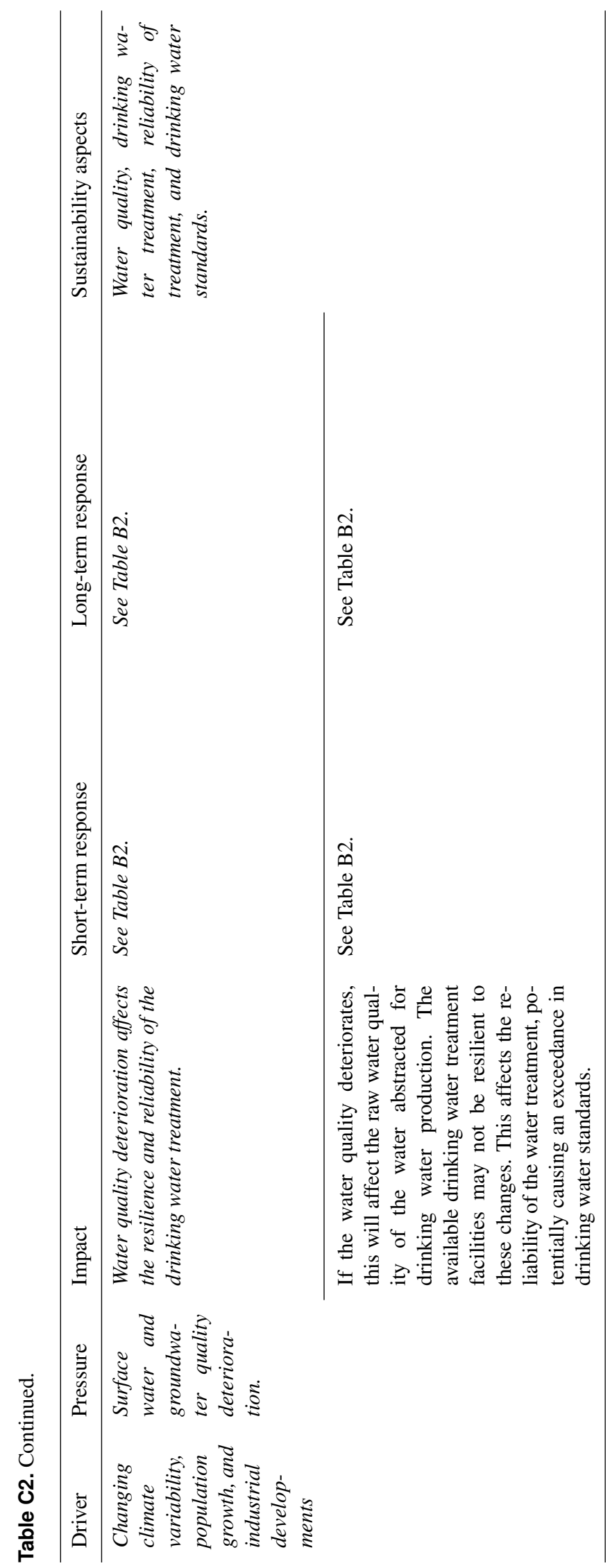




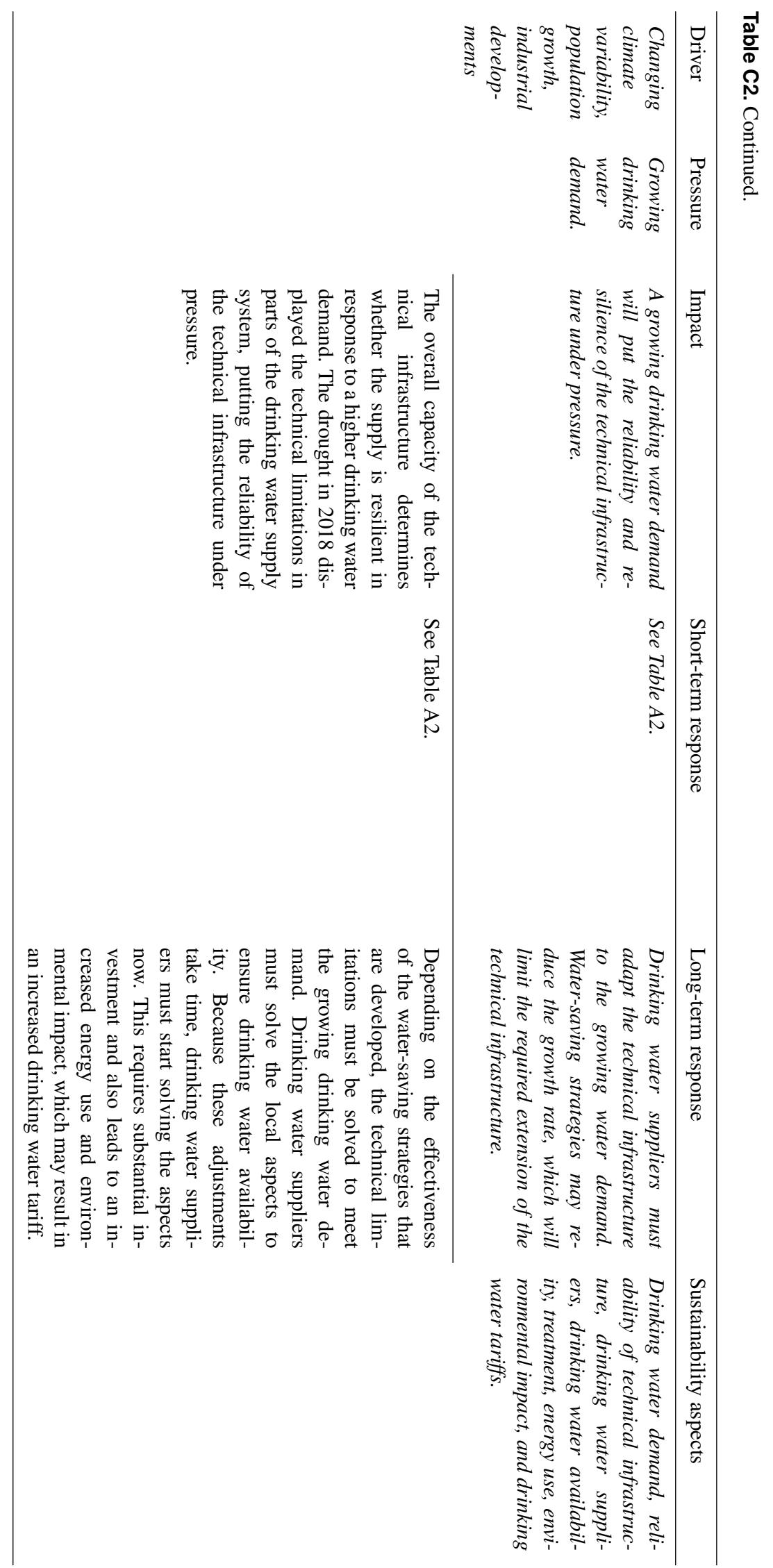




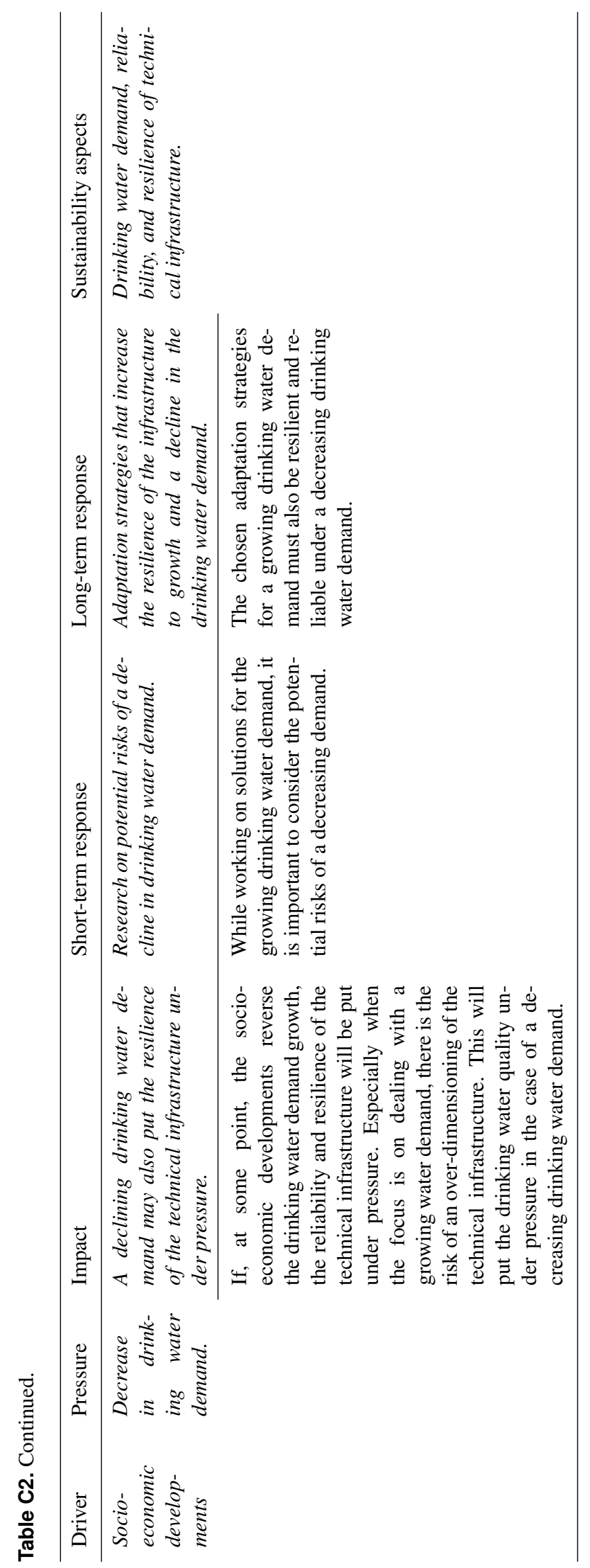




\section{Appendix D: Summary of Sustainable Development Goal 6 targets and indicators related to sustainability characteristics}

Table D1. Summary of the Sustainable Development Goal 6 targets and indicators related to sustainability characteristics.

\begin{tabular}{|c|c|c|c|c|c|c|c|c|c|c|}
\hline & & \multicolumn{3}{|c|}{$\begin{array}{l}\text { Hydrological } \\
\text { system }\end{array}$} & \multicolumn{3}{|c|}{ Technical system } & \multicolumn{3}{|c|}{$\begin{array}{c}\text { Socio-economic } \\
\text { system }\end{array}$} \\
\hline Target & Indicator & 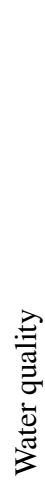 & 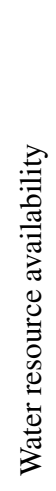 & 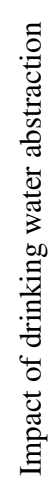 & 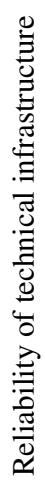 & 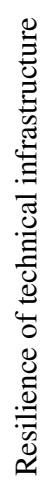 & 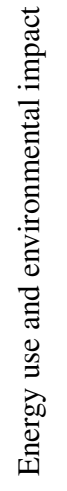 & 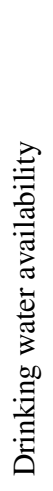 & 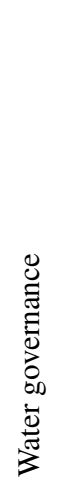 & 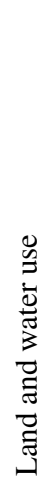 \\
\hline $\begin{array}{l}6.1 \text { By } 2030 \text {, achieve uni- } \\
\text { versal and equitable ac- } \\
\text { cess to safe and affordable } \\
\text { drinking water for all. }\end{array}$ & $\begin{array}{l}\text { 6.1.1 Proportion of popula- } \\
\text { tion using safely managed } \\
\text { drinking water services. }\end{array}$ & & & & $x$ & $x$ & & $\times$ & & \\
\hline $\begin{array}{l}6.2 \text { By } 2030 \text {, achieve ac- } \\
\text { cess to adequate and equi- } \\
\text { table sanitation and hygiene } \\
\text { for all and end open defe- } \\
\text { cation, paying special atten- } \\
\text { tion to the needs of women } \\
\text { and girls and those in vul- } \\
\text { nerable situations. }\end{array}$ & $\begin{array}{l}\text { 6.2.1 Proportion of the pop- } \\
\text { ulation using safely man- } \\
\text { aged sanitation services, in- } \\
\text { cluding a hand-washing fa- } \\
\text { cility with soap and water. }\end{array}$ & & & & & & & & & \\
\hline $\begin{array}{l}6.3 \text { By 2030, improve wa- } \\
\text { ter quality by reducing pol- } \\
\text { lution, eliminating dump- } \\
\text { ing, and minimizing the re- } \\
\text { lease of hazardous chem- } \\
\text { icals and materials, halv- } \\
\text { ing the proportion of un- } \\
\text { treated wastewater and sub- } \\
\text { stantially increasing recy- } \\
\text { cling and safe reuse glob- } \\
\text { ally. }\end{array}$ & $\begin{array}{l}\text { 6.3.1 Proportion of wastew- } \\
\text { ater safely treated. } \\
\text { 6.3.2 Proportion of bodies } \\
\text { of water with good ambient } \\
\text { water quality. }\end{array}$ & $\begin{array}{l}\times \\
\times\end{array}$ & & & & & & & $\begin{array}{l}\times \\
\times\end{array}$ & $\begin{array}{l}\times \\
\times\end{array}$ \\
\hline $\begin{array}{l}6.4 \text { By } 2030 \text {, substantially } \\
\text { increase water use effi- } \\
\text { ciency across all sectors, } \\
\text { and ensure sustainable } \\
\text { withdrawals and supply of } \\
\text { freshwater to address water } \\
\text { scarcity and substantially } \\
\text { reduce the number of peo- } \\
\text { ple suffering from water } \\
\text { scarcity. }\end{array}$ & $\begin{array}{l}\text { 6.4.1 Change in water-use } \\
\text { efficiency over time. } \\
\text { 6.4.2 Level of water stress } \\
\text { - freshwater withdrawal as } \\
\text { a proportion of available } \\
\text { freshwater resources. }\end{array}$ & & $\times$ & $\times$ & $\begin{array}{l}x \\
x\end{array}$ & $x$ & $\begin{array}{l}\times \\
\times\end{array}$ & & $\begin{array}{l}\times \\
\times\end{array}$ & $\begin{array}{l}\times \\
\times\end{array}$ \\
\hline
\end{tabular}


Table D1. Continued.

\begin{tabular}{|c|c|c|c|c|c|c|c|c|c|c|}
\hline \multirow[b]{2}{*}{ Target } & \multirow[b]{2}{*}{ Indicator } & \multicolumn{3}{|c|}{$\begin{array}{l}\text { Hydrological } \\
\text { system }\end{array}$} & \multicolumn{3}{|c|}{ Technical system } & \multicolumn{3}{|c|}{$\begin{array}{c}\text { Socio-economic } \\
\text { system }\end{array}$} \\
\hline & & 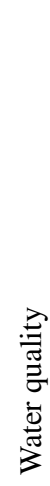 & 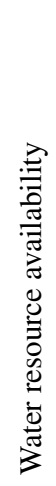 & 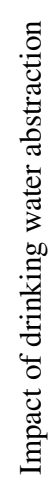 & 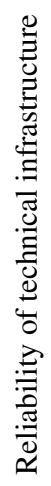 & 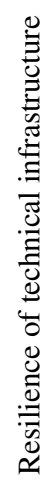 & 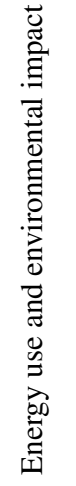 & 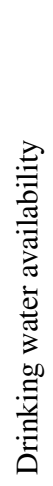 & 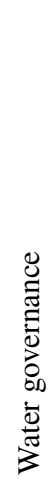 & 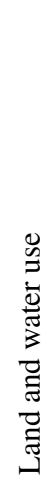 \\
\hline $\begin{array}{l}6.5 \text { By } 2030 \text {, implement } \\
\text { integrated water resources } \\
\text { management at all levels, } \\
\text { including through trans- } \\
\text { boundary cooperation, as } \\
\text { appropriate. }\end{array}$ & $\begin{array}{l}\text { 6.5.1 Degree of integrated } \\
\text { water resources manage- } \\
\text { ment implementation }(0- \\
100) \text {. } \\
6.5 .2 \text { Proportion of trans- } \\
\text { boundary basin area with an } \\
\text { operational arrangement for } \\
\text { water cooperation. }\end{array}$ & $x$ & $\times$ & & & & & & $\begin{array}{l}\times \\
\times\end{array}$ & \\
\hline $\begin{array}{l}6.6 \text { By 2020, protect } \\
\text { and restore water-related } \\
\text { ecosystems, including } \\
\text { mountains, forests, wet- } \\
\text { lands, rivers, aquifers, and } \\
\text { lakes. }\end{array}$ & $\begin{array}{l}\text { 6.6.1 Change in the extent } \\
\text { of water-related ecosystems } \\
\text { over time. }\end{array}$ & & & $\times$ & & & & & $x$ & \\
\hline $\begin{array}{l}\text { 6.a By } 2030 \text {, expand inter- } \\
\text { national cooperation and } \\
\text { capacity-building support } \\
\text { to developing countries in } \\
\text { water and sanitation-related } \\
\text { activities and programmes, } \\
\text { including water harvest- } \\
\text { ing, desalination, water } \\
\text { efficiency, wastewater } \\
\text { treatment, and recycling } \\
\text { and reuse technologies. }\end{array}$ & $\begin{array}{l}\text { 6.a.1 Amount of water- } \\
\text { and sanitation-related offi- } \\
\text { cial development assistance } \\
\text { that is part of a government- } \\
\text { coordinated spending plan. }\end{array}$ & & & & & & & & $x$ & \\
\hline $\begin{array}{l}\text { 6.b Support and strengthen } \\
\text { the participation of local } \\
\text { communities in improving } \\
\text { water and sanitation man- } \\
\text { agement. }\end{array}$ & $\begin{array}{l}\text { 6.b.1 Proportion of local ad- } \\
\text { ministrative units with es- } \\
\text { tablished and operational } \\
\text { policies and procedures for } \\
\text { participation of local com- } \\
\text { munities in water and sani- } \\
\text { tation management. }\end{array}$ & & & & & & & & $x$ & \\
\hline
\end{tabular}




\section{Appendix E: Overview of sustainability characteristics and criteria}

This section is an extended and updated version of Appendix A of Van Engelenburg et al. (2019).

Table E1. Summarizes the hydrological, technical, and socio-economic sustainability characteristics and criteria for a local drinking water supply system from Sect. 3 .

\begin{tabular}{|c|c|c|c|c|c|c|c|c|}
\hline System & $\begin{array}{l}\text { Sustainability } \\
\text { characteristics }\end{array}$ & $\begin{array}{l}\text { Sustainability } \\
\text { criteria }\end{array}$ & $\begin{array}{l}\text { General de- } \\
\text { scription }\end{array}$ & Sustainable & Under pressure & Unsustainable & $\begin{array}{l}\text { Suggestions for } \\
\text { general data } \\
\text { sources }\end{array}$ & $\begin{array}{l}\text { Reference for } \\
\text { general data } \\
\text { sources }\end{array}$ \\
\hline \multirow[t]{7}{*}{$\begin{array}{l}\text { Hydrological } \\
\text { system }\end{array}$} & \multirow[t]{5}{*}{ Water quality } & $\begin{array}{l}\text { Current raw } \\
\text { water quality }\end{array}$ & $\begin{array}{l}\text { To which extent } \\
\text { does the cur- } \\
\text { rent raw water } \\
\text { quality meet set } \\
\text { standards? }\end{array}$ & $\begin{array}{l}\text { Current raw } \\
\text { water qual- } \\
\text { ity meets set } \\
\text { standards. }\end{array}$ & $\begin{array}{l}\text { Occasionally } \\
\text { the current raw } \\
\text { water quality } \\
\text { exceeds set } \\
\text { standards. }\end{array}$ & $\begin{array}{l}\text { Current raw } \\
\text { water quality } \\
\text { is permanently } \\
\text { exceeding set } \\
\text { standards. }\end{array}$ & $\begin{array}{l}\text { E.g. status of } \\
\text { water bodies } \\
\text { according to } \\
\text { European Wa- } \\
\text { ter Framework } \\
\text { Directive. }\end{array}$ & $\begin{array}{l}\text { European } \\
\text { Union (2000). }\end{array}$ \\
\hline & & $\begin{array}{l}\text { Chemical as- } \\
\text { pects of water } \\
\text { quality }\end{array}$ & $\begin{array}{l}\text { Which trends } \\
\text { are found } \\
\text { in chemical } \\
\text { water quality } \\
\text { development? }\end{array}$ & $\begin{array}{l}\text { Chemical water } \\
\text { quality is im- } \\
\text { proving. }\end{array}$ & $\begin{array}{l}\text { Consistent } \\
\text { chemical water } \\
\text { quality. }\end{array}$ & $\begin{array}{l}\text { Deteriorating } \\
\text { chemical water } \\
\text { quality. }\end{array}$ & $\begin{array}{l}\text { European } \\
\text { Union (2000). }\end{array}$ & $\begin{array}{l}\text { European } \\
\text { Union (2000). }\end{array}$ \\
\hline & & $\begin{array}{l}\text { Microbial as- } \\
\text { pects of water } \\
\text { quality }\end{array}$ & $\begin{array}{l}\text { To which extent } \\
\text { is microbial } \\
\text { pollution a } \\
\text { threat to the } \\
\text { raw water } \\
\text { quality? }\end{array}$ & $\begin{array}{l}\text { No risk of } \\
\text { microbial } \\
\text { pollution. }\end{array}$ & $\begin{array}{l}\text { Microbial } \\
\text { pollution is } \\
\text { a potential } \\
\text { risk, but the } \\
\text { microbiologi- } \\
\text { cal quality is } \\
\text { sufficient. }\end{array}$ & $\begin{array}{l}\text { Microbial pol- } \\
\text { lution is an } \\
\text { actual risk, and } \\
\text { the microbio- } \\
\text { logical quality } \\
\text { is insufficient. }\end{array}$ & $\begin{array}{l}\text { European } \\
\text { Union (2000). }\end{array}$ & $\begin{array}{l}\text { European } \\
\text { Union (2000). }\end{array}$ \\
\hline & & $\begin{array}{l}\text { Acceptability } \\
\text { aspects of } \\
\text { water quality }\end{array}$ & $\begin{array}{l}\text { Are there as- } \\
\text { pects of water } \\
\text { quality that } \\
\text { limit the ac- } \\
\text { ceptability of } \\
\text { the drinking } \\
\text { water (saliniza- } \\
\text { tion, hardness, } \\
\text { and/or colour)? }\end{array}$ & $\begin{array}{l}\text { No issues with } \\
\text { the acceptabil- } \\
\text { ity of the drink- } \\
\text { ing water. }\end{array}$ & $\begin{array}{l}\text { Salinization, } \\
\text { hardness, or } \\
\text { colour cause } \\
\text { a minor ac- } \\
\text { ceptability } \\
\text { issue. }\end{array}$ & $\begin{array}{l}\text { Salinization, } \\
\text { hardness, } \\
\text { and/or colour } \\
\text { cause serious } \\
\text { acceptability } \\
\text { issues. }\end{array}$ & $\begin{array}{l}\text { European } \\
\text { Union (2000). }\end{array}$ & $\begin{array}{l}\text { European } \\
\text { Union (2000). }\end{array}$ \\
\hline & & $\begin{array}{l}\text { Monitoring and } \\
\text { evaluation of } \\
\text { water quality } \\
\text { trends }\end{array}$ & $\begin{array}{l}\text { Is there suf- } \\
\text { ficient and } \\
\text { adequate mon- } \\
\text { itoring and } \\
\text { evaluating of } \\
\text { water qual- } \\
\text { ity trends } \\
\text { available? }\end{array}$ & $\begin{array}{l}\text { Sufficient and } \\
\text { adequate mon- } \\
\text { itoring and } \\
\text { evaluating of } \\
\text { water quality } \\
\text { trends. }\end{array}$ & $\begin{array}{l}\text { There is } \\
\text { monitoring } \\
\text { available, but } \\
\text { the evaluation } \\
\text { of data is lim- } \\
\text { ited, resulting } \\
\text { in a limited } \\
\text { understanding } \\
\text { of water quality } \\
\text { trends. }\end{array}$ & $\begin{array}{l}\text { There is lim- } \\
\text { ited or no } \\
\text { monitoring } \\
\text { available, and } \\
\text { water quality } \\
\text { trends are not } \\
\text { investigated. }\end{array}$ & $\begin{array}{l}\text { European } \\
\text { Union (2000). }\end{array}$ & $\begin{array}{l}\text { European } \\
\text { Union (2000). }\end{array}$ \\
\hline & \multirow[t]{2}{*}{$\begin{array}{l}\text { Water resource } \\
\text { availability }\end{array}$} & $\begin{array}{l}\text { Surface water } \\
\text { quantity }\end{array}$ & $\begin{array}{l}\text { Are there } \\
\text { current lim- } \\
\text { itations or } \\
\text { future threats to } \\
\text { the abstracted } \\
\text { surface water } \\
\text { volume? }\end{array}$ & $\begin{array}{l}\text { Sufficient avail- } \\
\text { ability all year } \\
\text { round or no sur- } \\
\text { face water ab- } \\
\text { straction. }\end{array}$ & $\begin{array}{l}\text { Surface water } \\
\text { availability } \\
\text { varies during } \\
\text { the year and } \\
\text { may occasion- } \\
\text { ally be limited } \\
\text { in the case of } \\
\text { dry weather } \\
\text { conditions. }\end{array}$ & $\begin{array}{l}\text { There is } \\
\text { regularly insuf- } \\
\text { ficient surface } \\
\text { water volume } \\
\text { available in the } \\
\text { dry season. }\end{array}$ & $\begin{array}{l}\text { E.g. status of } \\
\text { water bodies } \\
\text { according to } \\
\text { European Wa- } \\
\text { ter Framework } \\
\text { Directive. }\end{array}$ & $\begin{array}{l}\text { European } \\
\text { Union (2000). }\end{array}$ \\
\hline & & $\begin{array}{l}\text { Groundwater } \\
\text { quantity }\end{array}$ & $\begin{array}{l}\text { Are there } \\
\text { current lim- } \\
\text { itations or } \\
\text { future threats to } \\
\text { the abstracted } \\
\text { groundwater } \\
\text { volume? }\end{array}$ & $\begin{array}{l}\text { Abstraction } \\
\text { is not lim- } \\
\text { ited because } \\
\text { groundwater } \\
\text { is recharged } \\
\text { sufficiently } \\
\text { (yearly abstrac- } \\
\text { tion < annual } \\
\text { recharge minus } \\
\text { environmental } \\
\text { streamflow) or } \\
\text { no groundwater } \\
\text { abstraction. }\end{array}$ & $\begin{array}{l}\text { Abstraction is } \\
\text { not limited but } \\
\text { exceeds annual } \\
\text { recharge minus } \\
\text { environmental } \\
\text { streamflow. }\end{array}$ & $\begin{array}{l}\text { Abstraction } \\
\text { volume is lim- } \\
\text { ited because } \\
\text { groundwater } \\
\text { is abstracted } \\
\text { from a confined } \\
\text { aquifer that is } \\
\text { not recharged } \\
\text { (mining). }\end{array}$ & $\begin{array}{l}\text { E.g. status of } \\
\text { water bodies } \\
\text { according to } \\
\text { European Wa- } \\
\text { ter Framework } \\
\text { Directive. }\end{array}$ & $\begin{array}{l}\text { European } \\
\text { Union (2000). }\end{array}$ \\
\hline
\end{tabular}


Table E1. Continued.

\begin{tabular}{|c|c|c|c|c|c|c|c|c|}
\hline System & $\begin{array}{l}\text { Sustainability } \\
\text { characteristics }\end{array}$ & $\begin{array}{l}\text { Sustainability } \\
\text { criteria }\end{array}$ & $\begin{array}{l}\text { General de- } \\
\text { scription }\end{array}$ & Sustainable & Under pressure & Unsustainable & $\begin{array}{l}\text { Suggestions for } \\
\text { general data } \\
\text { sources }\end{array}$ & $\begin{array}{l}\text { Reference for } \\
\text { general data } \\
\text { sources }\end{array}$ \\
\hline & & $\begin{array}{l}\text { Other available } \\
\text { water resources }\end{array}$ & $\begin{array}{l}\text { Are there wa- } \\
\text { ter resources } \\
\text { available for } \\
\text { drinking water } \\
\text { production } \\
\text { other than } \\
\text { currently used? }\end{array}$ & $\begin{array}{l}\text { There are suf- } \\
\text { ficient water } \\
\text { resources avail- } \\
\text { able that could } \\
\text { replace the } \\
\text { currently used } \\
\text { water resource } \\
\text { with minor } \\
\text { adjustments to } \\
\text { the drinking } \\
\text { water treatment } \\
\text { method. }\end{array}$ & $\begin{array}{l}\text { There are other } \\
\text { water resources } \\
\text { available that } \\
\text { could replace } \\
\text { the currently } \\
\text { used water } \\
\text { resource, but } \\
\text { this will re- } \\
\text { quire major } \\
\text { adjustments to } \\
\text { the drinking } \\
\text { water treatment } \\
\text { method. }\end{array}$ & $\begin{array}{l}\text { There are no } \\
\text { water resources } \\
\text { available that } \\
\text { could replace } \\
\text { the current used } \\
\text { water resource. }\end{array}$ & $\begin{array}{l}\text { E.g. status of } \\
\text { water bodies } \\
\text { according to } \\
\text { European Wa- } \\
\text { ter Framework } \\
\text { Directive. }\end{array}$ & $\begin{array}{l}\text { European } \\
\text { Union (2000). }\end{array}$ \\
\hline & & $\begin{array}{l}\text { Vulnerability of } \\
\text { used water sys- } \\
\text { tem to contami- } \\
\text { nation }\end{array}$ & $\begin{array}{l}\text { To which extent } \\
\text { is the used wa- } \\
\text { ter system vul- } \\
\text { nerable to con- } \\
\text { tamination? }\end{array}$ & $\begin{array}{l}\text { The water sys- } \\
\text { tem is hardly } \\
\text { vulnerable to } \\
\text { contamination } \\
\text { because the } \\
\text { used water } \\
\text { resource is } \\
\text { protected by } \\
\text { an aquitard } \\
\text { (groundwater } \\
\text { in confined } \\
\text { aquifers). }\end{array}$ & $\begin{array}{l}\text { The water } \\
\text { system is vul- } \\
\text { nerable to soil } \\
\text { and groundwa- } \\
\text { ter pollution } \\
\text { (phreatic } \\
\text { groundwater). }\end{array}$ & $\begin{array}{l}\text { The water } \\
\text { system is } \\
\text { vulnerable to } \\
\text { calamities and } \\
\text { diffuse contam- } \\
\text { ination (surface } \\
\text { water). }\end{array}$ & $\begin{array}{l}\text { E.g. status of } \\
\text { water bodies } \\
\text { according to } \\
\text { European Wa- } \\
\text { ter Framework } \\
\text { Directive. }\end{array}$ & $\begin{array}{l}\text { European } \\
\text { Union (2000). }\end{array}$ \\
\hline & & $\begin{array}{l}\text { Natural hazards } \\
\text { and emergen- } \\
\text { cies risk }\end{array}$ & $\begin{array}{l}\text { To which extent } \\
\text { are natural haz- } \\
\text { ards (droughts, } \\
\text { floods, earth- } \\
\text { quakes, and } \\
\text { forest fires) } \\
\text { threatening the } \\
\text { water resources } \\
\text { availability? }\end{array}$ & $\begin{array}{l}\text { Limited risk } \\
\text { of natural haz- } \\
\text { ards }(<1 \text { per } \\
25 \text { years }) \text {. }\end{array}$ & $\begin{array}{l}\text { Minor risk of } \\
\text { a natural haz- } \\
\text { ards }(<1 \text { per } \\
10 \text { years }) \text {. }\end{array}$ & $\begin{array}{l}\text { Natural haz- } \\
\text { ards occur } \\
\text { frequently }(>1 \\
\text { per } 10 \text { years) } \\
\text { and are a se- } \\
\text { rious threat to } \\
\text { water resources } \\
\text { availability. }\end{array}$ & $\begin{array}{l}\text { E.g. national } \\
\text { flood risk in- } \\
\text { ventory and } \\
\text { Commission } \\
\text { on Sustainable } \\
\text { Development } \\
\text { (CSD) In- } \\
\text { dicator of } \\
\text { Sustainable } \\
\text { Development } \\
\text { (percentage } \\
\text { of popula- } \\
\text { tion living in } \\
\text { hazard-prone } \\
\text { areas). }\end{array}$ & UN (2007). \\
\hline & $\begin{array}{l}\text { Impact of } \\
\text { drinking water } \\
\text { abstraction }\end{array}$ & $\begin{array}{l}\text { Impact on sur- } \\
\text { face water sys- } \\
\text { tem }\end{array}$ & $\begin{array}{l}\text { The scale of } \\
\text { impact of the } \\
\text { abstraction to } \\
\text { the surface } \\
\text { water system. }\end{array}$ & $\begin{array}{l}\text { Small (ground- } \\
\text { water abstrac- } \\
\text { tion below } \\
\text { aquitard). }\end{array}$ & $\begin{array}{l}\text { Medium (river- } \\
\text { bank abstrac- } \\
\text { tion; phreatic } \\
\text { groundwater } \\
\text { abstraction). }\end{array}$ & $\begin{array}{l}\text { Large (sur- } \\
\text { face water } \\
\text { abstraction). }\end{array}$ & $\begin{array}{l}\text { E.g. status of } \\
\text { water bodies } \\
\text { according to } \\
\text { European Wa- } \\
\text { ter Framework } \\
\text { Directive. }\end{array}$ & $\begin{array}{l}\text { European } \\
\text { Union (2000). }\end{array}$ \\
\hline & & $\begin{array}{l}\text { Impact to } \\
\text { groundwater } \\
\text { system }\end{array}$ & $\begin{array}{l}\text { The scale of } \\
\text { impact of the } \\
\text { abstraction to } \\
\text { the groundwa- } \\
\text { ter system. }\end{array}$ & $\begin{array}{l}\text { Small (sur- } \\
\text { face water } \\
\text { abstraction). }\end{array}$ & $\begin{array}{l}\text { Medium } \\
\text { (riverbank } \\
\text { abstraction; } \\
\text { groundwater } \\
\text { abstraction be- } \\
\text { low aquitard). }\end{array}$ & $\begin{array}{l}\text { Large (phreatic } \\
\text { groundwater } \\
\text { abstraction). }\end{array}$ & $\begin{array}{l}\text { E.g. groundwa- } \\
\text { ter footprint. }\end{array}$ & $\begin{array}{l}\text { Gleeson and } \\
\text { Wada (2013). }\end{array}$ \\
\hline & & $\begin{array}{l}\text { Balance be- } \\
\text { tween annual } \\
\text { recharge and } \\
\text { abstraction }\end{array}$ & $\begin{array}{l}\text { The balance } \\
\text { between ab- } \\
\text { straction and } \\
\text { recharge of the } \\
\text { water system. }\end{array}$ & $\begin{array}{l}\text { The net abstrac- } \\
\text { tion volume is } \\
\text { less than } 10 \% \\
\text { of the average } \\
\text { annual recharge } \\
\text { in the recharge } \\
\text { area. }\end{array}$ & $\begin{array}{l}\text { The net abstrac- } \\
\text { tion volume } \\
\text { is } 10 \%-40 \% \\
\text { of the average } \\
\text { annual recharge } \\
\text { in the recharge } \\
\text { area. }\end{array}$ & $\begin{array}{l}\text { The net abstrac- } \\
\text { tion volume } \\
\text { is }>40 \% \text { of } \\
\text { the average } \\
\text { annual recharge } \\
\text { in the recharge } \\
\text { area. }\end{array}$ & $\begin{array}{l}\text { Sustainable } \\
\text { Society Index } \\
\text { (SSI; renew- } \\
\text { able water } \\
\text { resources). }\end{array}$ & $\begin{array}{l}\text { Van der Kerk } \\
\text { and Manuel } \\
(2008) \text {. }\end{array}$ \\
\hline & & $\begin{array}{l}\text { Hydrological } \\
\text { compensation }\end{array}$ & $\begin{array}{l}\text { The extent to } \\
\text { which the im- } \\
\text { pact of abstrac- } \\
\text { tion is compen- } \\
\text { sated hydrolog- } \\
\text { ically. }\end{array}$ & $\begin{array}{l}\text { Small impact } \\
\text { or impact is } \\
\text { hydrologically } \\
\text { compensated } \\
\text { with a technical } \\
\text { measure. }\end{array}$ & $\begin{array}{l}\text { There are pos- } \\
\text { sibilities for hy- } \\
\text { drological com- } \\
\text { pensation of the } \\
\text { impact on the } \\
\text { abstraction, but } \\
\text { they are not op- } \\
\text { erational yet. }\end{array}$ & $\begin{array}{l}\text { There is a sig- } \\
\text { nificant impact } \\
\text { on the abstrac- } \\
\text { tion, but there } \\
\text { are no possi- } \\
\text { bilities for hy- } \\
\text { drological com- } \\
\text { pensation. }\end{array}$ & $\begin{array}{l}\text { Local hy- } \\
\text { drological } \\
\text { knowledge; } \\
\text { hydrological } \\
\text { modelling } \\
\text { results. }\end{array}$ & $\begin{array}{l}\text { E.g. Van En- } \\
\text { gelenburg } \\
\text { et al. (2018, } \\
2020) .\end{array}$ \\
\hline
\end{tabular}


Table E1. Continued.

\begin{tabular}{|c|c|c|c|c|c|c|c|c|}
\hline System & $\begin{array}{l}\text { Sustainability } \\
\text { characteristics }\end{array}$ & $\begin{array}{l}\text { Sustainability } \\
\text { criteria }\end{array}$ & $\begin{array}{l}\text { General de- } \\
\text { scription }\end{array}$ & Sustainable & Under pressure & Unsustainable & $\begin{array}{l}\text { Suggestions for } \\
\text { general data } \\
\text { sources }\end{array}$ & $\begin{array}{lr}\text { Reference for } \\
\text { general data } \\
\text { sources }\end{array}$ \\
\hline & & $\begin{array}{l}\text { Spatial impact } \\
\text { of abstraction } \\
\text { facility, stor- } \\
\text { age, and/or } \\
\text { reservoir }\end{array}$ & $\begin{array}{l}\text { Size of required } \\
\text { working area } \\
\text { for abstraction } \\
\text { facility. }\end{array}$ & $\begin{array}{l}\text { Small (ground- } \\
\text { water ab- } \\
\text { straction with } \\
\text { basic treatment } \\
\text { facility). }\end{array}$ & $\begin{array}{l}\text { Medium } \\
\text { (groundwater } \\
\text { abstraction } \\
\text { with medium } \\
\text { treatment } \\
\text { facility). }\end{array}$ & $\begin{array}{l}\text { Large (surface } \\
\text { water ab- } \\
\text { straction with } \\
\text { storage basins } \\
\text { and extended } \\
\text { treatment } \\
\text { facility). }\end{array}$ & $\begin{array}{l}\text { Drinking water } \\
\text { company's } \\
\text { information; } \\
\text { map. }\end{array}$ & \\
\hline \multirow[t]{6}{*}{$\begin{array}{l}\text { Technical sys- } \\
\text { tem }\end{array}$} & \multirow[t]{5}{*}{$\begin{array}{l}\text { Reliability } \\
\text { of technical } \\
\text { infrastructure }\end{array}$} & $\begin{array}{l}\text { Technical state } \\
\text { abstraction and } \\
\text { treatment facil- } \\
\text { ity }\end{array}$ & $\begin{array}{l}\text { Is the techni- } \\
\text { cal state of the } \\
\text { drinking water } \\
\text { production fa- } \\
\text { cility sufficient } \\
\text { and fully de- } \\
\text { ployable? }\end{array}$ & $\begin{array}{l}\text { The technical } \\
\text { state of the } \\
\text { drinking water } \\
\text { production } \\
\text { facility is suffi- } \\
\text { cient and fully } \\
\text { deployable. }\end{array}$ & $\begin{array}{l}\text { Production } \\
\text { capacity is } \\
\text { sufficient but } \\
\text { not fully de- } \\
\text { ployable due } \\
\text { to restrictions } \\
\text { in permit } \\
\text { or technical } \\
\text { limitations. }\end{array}$ & $\begin{array}{l}\text { Production ca- } \\
\text { pacity is insuf- } \\
\text { ficient due to } \\
\text { technical limi- } \\
\text { tations. }\end{array}$ & $\begin{array}{l}\text { International } \\
\text { Water Associa- } \\
\text { tion (IWA; pH1 } \\
\text { treatment plant } \\
\text { utilization). }\end{array}$ & $\begin{array}{l}\text { Alegre } \\
\text { et al. (2006). }\end{array}$ \\
\hline & & $\begin{array}{l}\text { Technical state } \\
\text { distribution in- } \\
\text { frastructure }\end{array}$ & $\begin{array}{l}\text { Are there } \\
\text { issues that } \\
\text { complicate the } \\
\text { drinking water } \\
\text { distribution? }\end{array}$ & $\begin{array}{l}\text { The distribu- } \\
\text { tion infrastruc- } \\
\text { ture is adequate } \\
\text { to meet the } \\
\text { required distri- } \\
\text { bution capacity } \\
\text { and water } \\
\text { pressure. }\end{array}$ & $\begin{array}{l}\text { The distribu- } \\
\text { tion infrastruc- } \\
\text { ture is adequate } \\
\text { in general but, } \\
\text { at extreme peak } \\
\text { demand, lim- } \\
\text { itations in the } \\
\text { drinking water } \\
\text { distribution } \\
\text { cause reduced } \\
\text { water pressure } \\
\text { and limited } \\
\text { drinking water } \\
\text { supply. }\end{array}$ & $\begin{array}{l}\text { The distribu- } \\
\text { tion infras- } \\
\text { tructure is } \\
\text { insufficient and } \\
\text { major disrup- } \\
\text { tions of the } \\
\text { drinking water } \\
\text { supply occur } \\
\text { regularly. }\end{array}$ & $\begin{array}{l}\text { Performance } \\
\text { data of water } \\
\text { utilities. }\end{array}$ & $\begin{array}{l}\text { E.g. Dutch } \\
\text { Government } \\
\text { (2009a). }\end{array}$ \\
\hline & & $\begin{array}{l}\text { Complexity of } \\
\text { water treatment }\end{array}$ & $\begin{array}{l}\text { How complex } \\
\text { is the required } \\
\text { treatment. and } \\
\text { is the treatment } \\
\text { effective to } \\
\text { meet the water } \\
\text { quality issues? }\end{array}$ & $\begin{array}{l}\text { Technical water } \\
\text { quality issues } \\
\text { (iron/manganese } \\
\text { removal and } \\
\text { pH correction); } \\
\text { requires only } \\
\text { basic treatment. }\end{array}$ & $\begin{array}{l}\text { Water quality } \\
\text { issues such as } \\
\text { hardness re- } \\
\text { quire medium } \\
\text { complex } \\
\text { treatment (de- } \\
\text { calcification). }\end{array}$ & $\begin{array}{l}\text { Serious water } \\
\text { quality issues } \\
\text { (chemical and } \\
\text { microbiolog- } \\
\text { ical) require } \\
\text { a complex } \\
\text { treatment } \\
\text { (ultra-filtration } \\
\text { and reverse } \\
\text { osmosis). }\end{array}$ & $\begin{array}{l}\text { Performance } \\
\text { data of water } \\
\text { utilities. }\end{array}$ & $\begin{array}{l}\text { E.g. Dutch } \\
\text { Government } \\
\text { (2009a). }\end{array}$ \\
\hline & & $\begin{array}{l}\text { Supply con- } \\
\text { tinuity for } \\
\text { customers }\end{array}$ & $\begin{array}{l}\text { Are there fre- } \\
\text { quent drinking } \\
\text { water supply } \\
\text { interruptions? }\end{array}$ & $\begin{array}{l}\text { Drinking water } \\
\text { supply inter- } \\
\text { ruptions }<1 \mathrm{~h} \\
\text { per year. }\end{array}$ & $\begin{array}{l}\text { Drinking water } \\
\text { supply inter- } \\
\text { ruptions }<10 \mathrm{~d} \\
\text { per year. }\end{array}$ & $\begin{array}{l}\text { Drinking water } \\
\text { supply inter- } \\
\text { ruptions }>10 \mathrm{~d} \\
\text { per year. }\end{array}$ & $\begin{array}{l}\text { Performance } \\
\text { data of water } \\
\text { utilities; IWA } \\
\text { (QS17 days } \\
\text { with restric- } \\
\text { tions to water } \\
\text { service). }\end{array}$ & $\begin{array}{l}\text { Alegre } \\
\text { et al. (2006). }\end{array}$ \\
\hline & & $\begin{array}{l}\text { Operational re- } \\
\text { liability }\end{array}$ & $\begin{array}{l}\text { Is the facility } \\
\text { operationally } \\
\text { reliable? }\end{array}$ & $\begin{array}{l}\text { Facility meets } \\
\text { corporate } \\
\text { standard for } \\
\text { operational } \\
\text { reliability. }\end{array}$ & $\begin{array}{l}\text { The facility } \\
\text { does not fully } \\
\text { meet corporate } \\
\text { standard for } \\
\text { operational } \\
\text { reliability, but } \\
\text { investments } \\
\text { are planned } \\
\text { to increase } \\
\text { the opera- } \\
\text { tional reliabil- } \\
\text { ity }<5 \text { years. }\end{array}$ & $\begin{array}{l}\text { Facility is not } \\
\text { operationally } \\
\text { reliable, and } \\
\text { there are no } \\
\text { investments } \\
\text { planned to } \\
\text { improve the re- } \\
\text { liability within } \\
5 \text { years. }\end{array}$ & $\begin{array}{l}\text { Performance } \\
\text { data of water } \\
\text { utilities. }\end{array}$ & $\begin{array}{l}\text { E.g. Dutch } \\
\text { Government } \\
\text { (2009a). }\end{array}$ \\
\hline & $\begin{array}{l}\text { Resilience } \\
\text { of technical } \\
\text { infrastructure }\end{array}$ & $\begin{array}{l}\text { Abstraction } \\
\text { permit com- } \\
\text { pared to annual } \\
\text { drinking water } \\
\text { demand }\end{array}$ & $\begin{array}{l}\text { Are the permit- } \\
\text { ted abstraction } \\
\text { volumes suffi- } \\
\text { cient to meet } \\
\text { the annual } \\
\text { drinking water } \\
\text { demand? }\end{array}$ & $\begin{array}{l}\text { The permitted } \\
\text { abstraction } \\
\text { volumes are } \\
\text { sufficient to } \\
\text { meet the cur- } \\
\text { rent and future } \\
\text { annual drinking } \\
\text { water demand } \\
\text { (operational re- } \\
\text { serve }>10 \% \text { ). }\end{array}$ & $\begin{array}{l}\text { The permitted } \\
\text { abstraction } \\
\text { volumes are } \\
\text { sufficient to } \\
\text { meet the cur- } \\
\text { rent annual } \\
\text { drinking water } \\
\text { demand but } \\
\text { cannot meet the } \\
\text { future demand } \\
\text { (operational re- } \\
\text { serve }<10 \% \text { ). }\end{array}$ & $\begin{array}{l}\text { The permitted } \\
\text { abstraction } \\
\text { volumes are } \\
\text { insufficient to } \\
\text { meet the cur- } \\
\text { rent or future } \\
\text { annual drinking } \\
\text { water demand. }\end{array}$ & $\begin{array}{l}\text { Performance } \\
\text { data of water } \\
\text { utilities. }\end{array}$ & $\begin{array}{l}\text { E.g. Dutch } \\
\text { Government } \\
(2009 b) \text {. }\end{array}$ \\
\hline
\end{tabular}


Table E1. Continued.

\begin{tabular}{|c|c|c|c|c|c|c|c|c|}
\hline System & $\begin{array}{l}\text { Sustainability } \\
\text { characteristics }\end{array}$ & $\begin{array}{l}\text { Sustainability } \\
\text { criteria }\end{array}$ & $\begin{array}{l}\text { General de- } \\
\text { scription }\end{array}$ & Sustainable & Under pressure & Unsustainable & $\begin{array}{l}\text { Suggestions for } \\
\text { general data } \\
\text { sources }\end{array}$ & $\begin{array}{l}\text { Reference for } \\
\text { general data } \\
\text { sources }\end{array}$ \\
\hline & & $\begin{array}{l}\text { Production } \\
\text { capacity com- } \\
\text { pared to peak } \\
\text { demand }\end{array}$ & $\begin{array}{l}\text { Is the produc- } \\
\text { tion capacity } \\
\text { per hour suffi- } \\
\text { cient to meet } \\
\text { extreme peak } \\
\text { demand? }\end{array}$ & $\begin{array}{l}\text { The production } \\
\text { capacity per } \\
\text { hour is suffi- } \\
\text { cient to meet } \\
\text { extreme peak } \\
\text { demand. }\end{array}$ & $\begin{array}{l}\text { The produc- } \\
\text { tion capacity } \\
\text { is }<5 \% \text { below } \\
\text { the predicted } \\
\text { extreme peak } \\
\text { demand and, } \\
\text { therefore, is not } \\
\text { fully sufficient. }\end{array}$ & $\begin{array}{l}\text { The produc- } \\
\text { tion capacity } \\
\text { is }>5 \% \text { below } \\
\text { the predicted } \\
\text { extreme peak } \\
\text { demand and, } \\
\text { therefore, is } \\
\text { insufficient } \\
\text { to meet peak } \\
\text { demand. }\end{array}$ & $\begin{array}{l}\text { Performance } \\
\text { data of water } \\
\text { utilities; IWA } \\
\text { (pH1 treat- } \\
\text { ment plant } \\
\text { utilization). }\end{array}$ & $\begin{array}{l}\text { Alegre } \\
\text { et al. (2006) }\end{array}$ \\
\hline & & $\begin{array}{l}\text { Flexibility } \\
\text { of treatment } \\
\text { method for } \\
\text { changing raw } \\
\text { water quality }\end{array}$ & $\begin{array}{l}\text { Is the treatment } \\
\text { method flexible } \\
\text { in response to } \\
\text { a changing raw } \\
\text { water quality? }\end{array}$ & $\begin{array}{l}\text { The treatment } \\
\text { method re- } \\
\text { moves a broad } \\
\text { spectrum of } \\
\text { pollutants and } \\
\text { can therefore } \\
\text { also handle } \\
\text { various new } \\
\text { pollutants (e.g. } \\
\text { membrane } \\
\text { treatment } \\
\text { methods). }\end{array}$ & $\begin{array}{l}\text { The treatment } \\
\text { method is } \\
\text { flexible when } \\
\text { concentrations } \\
\text { of the currently } \\
\text { removed ele- } \\
\text { ments change } \\
\text { but cannot } \\
\text { remove other } \\
\text { pollutants (e.g. } \\
\text { decalcifica- } \\
\text { tion). }\end{array}$ & $\begin{array}{l}\text { The treatment } \\
\text { method is not } \\
\text { flexible in re- } \\
\text { sponse to large } \\
\text { changes in con- } \\
\text { centrations or } \\
\text { pollutants (e.g. } \\
\text { sand filtration). }\end{array}$ & $\begin{array}{l}\text { Performance } \\
\text { data of water } \\
\text { utilities. }\end{array}$ & \\
\hline & & $\begin{array}{l}\text { Technical inno- } \\
\text { vations to im- } \\
\text { prove resilience }\end{array}$ & $\begin{array}{l}\text { Have technical } \\
\text { innovations } \\
\text { been developed } \\
\text { to improve } \\
\text { resilience? }\end{array}$ & $\begin{array}{l}\text { Within society } \\
\text { there is ongo- } \\
\text { ing research to } \\
\text { find technical } \\
\text { innovations on } \\
\text { drinking water } \\
\text { use or supply } \\
\text { to improve } \\
\text { resilience. }\end{array}$ & $\begin{array}{l}\text { Within the } \\
\text { drinking water } \\
\text { company there } \\
\text { is ongoing } \\
\text { research to } \\
\text { find technical } \\
\text { innovations } \\
\text { for drinking } \\
\text { water supply } \\
\text { to improve } \\
\text { resilience. }\end{array}$ & $\begin{array}{l}\text { There is no } \\
\text { or limited } \\
\text { research on } \\
\text { technical in- } \\
\text { novations for } \\
\text { drinking water } \\
\text { supply. }\end{array}$ & $\begin{array}{l}\text { Data of water } \\
\text { utilities (annual } \\
\text { report). }\end{array}$ & \\
\hline & & $\begin{array}{l}\text { Technical } \\
\text { investments } \\
\text { to improve } \\
\text { resilience }\end{array}$ & $\begin{array}{l}\text { Are technical } \\
\text { investments } \\
\text { being made } \\
\text { to improve } \\
\text { resilience? }\end{array}$ & $\begin{array}{l}\text { Technical in- } \\
\text { vestments are } \\
\text { being made to } \\
\text { improve the } \\
\text { resilience of the } \\
\text { drinking water } \\
\text { infrastruc- } \\
\text { ture, including } \\
\text { investments } \\
\text { in technical } \\
\text { innovations. }\end{array}$ & $\begin{array}{l}\text { There is a } \\
\text { limited budget } \\
\text { for technical } \\
\text { investments to } \\
\text { improve the } \\
\text { resilience of the } \\
\text { drinking water } \\
\text { infrastructure. }\end{array}$ & $\begin{array}{l}\text { There is no } \\
\text { budget for } \\
\text { technical } \\
\text { investments. }\end{array}$ & $\begin{array}{l}\text { Financial } \\
\text { data of water } \\
\text { utilities. }\end{array}$ & \\
\hline & $\begin{array}{l}\text { Energy use and } \\
\text { environmental } \\
\text { impact }\end{array}$ & $\begin{array}{l}\text { Energy use of } \\
\text { abstraction and } \\
\text { treatment }\end{array}$ & $\begin{array}{l}\text { Energy use } \\
\text { for abstraction } \\
\text { and treatment } \\
\text { of water per } \\
\text { square metre. }\end{array}$ & $\begin{array}{l}\text { Low (shallow } \\
\text { groundwater } \\
\text { abstraction, } \\
\text { short distance } \\
\text { to treatment, } \\
\text { and basic } \\
\text { treatment), }\end{array}$ & $\begin{array}{l}\text { Average (deep } \\
\text { groundwater } \\
\text { abstraction, } \\
\text { short distance } \\
\text { to treatment, } \\
\text { and medium } \\
\text { treatment } \\
\text { groundwater). }\end{array}$ & $\begin{array}{l}\text { High (long } \\
\text { transport } \\
\text { distance to } \\
\text { treatment } \\
\text { and complex } \\
\text { treatment). }\end{array}$ & $\begin{array}{l}\text { IWA; pH5 } \\
\text { standardized } \\
\text { energy con- } \\
\text { sumption. }\end{array}$ & $\begin{array}{l}\text { Alegre } \\
\text { et al. (2006). }\end{array}$ \\
\hline & & $\begin{array}{l}\text { Energy use of } \\
\text { distribution }\end{array}$ & $\begin{array}{l}\text { Energy use for } \\
\text { distribution. }\end{array}$ & $\begin{array}{l}\text { Low (aver- } \\
\text { age transport } \\
\text { distances } \\
<15 \mathrm{~km}) \text {. }\end{array}$ & $\begin{array}{l}\text { Average (aver- } \\
\text { age transport } \\
\text { distances } \\
<30 \mathrm{~km} \text { ). }\end{array}$ & $\begin{array}{l}\text { High (aver- } \\
\text { age transport } \\
\text { distances } \\
>30 \mathrm{~km})\end{array}$ & $\begin{array}{l}\text { European } \\
\text { Benchmark } \\
\text { (EBC; electric- } \\
\text { ity use). }\end{array}$ & $\begin{array}{l}\text { European } \\
\text { Benchmarking } \\
\text { Co-operation } \\
\text { (2017). }\end{array}$ \\
\hline & & $\begin{array}{l}\text { Environmental } \\
\text { impact (ad- } \\
\text { ditional } \\
\text { excipients, } \\
\text { wastewater, } \\
\text { and waste } \\
\text { materials) }\end{array}$ & $\begin{array}{l}\text { Are there ma- } \\
\text { terials used or } \\
\text { produced in the } \\
\text { treatment with } \\
\text { an environmen- } \\
\text { tal impact? }\end{array}$ & $\begin{array}{l}\text { No use or } \\
\text { production } \\
\text { of materials } \\
\text { with high en- } \\
\text { vironmental } \\
\text { impact. }\end{array}$ & $\begin{array}{l}\text { Use of addi- } \\
\text { tional excipi- } \\
\text { ents with high } \\
\text { environmental } \\
\text { impact in the } \\
\text { treatment. }\end{array}$ & $\begin{array}{l}\text { Production of } \\
\text { waste materials } \\
\text { and wastewa- } \\
\text { ter with high } \\
\text { environmental } \\
\text { impact. }\end{array}$ & $\begin{array}{l}\text { EBC (climate } \\
\text { footprint). }\end{array}$ & $\begin{array}{l}\text { European } \\
\text { Benchmarking } \\
\text { Co-operation } \\
\text { (2017). }\end{array}$ \\
\hline & & $\begin{array}{l}\text { Reliability en- } \\
\text { ergy supply }\end{array}$ & $\begin{array}{l}\text { Is the energy } \\
\text { supply reliable? }\end{array}$ & $\begin{array}{l}\text { Reliable energy } \\
\text { supply and } \\
\text { emergency } \\
\text { energy backup. }\end{array}$ & $\begin{array}{l}\text { Average re- } \\
\text { liable energy } \\
\text { supply and } \\
\text { no emergency } \\
\text { energy backup. }\end{array}$ & $\begin{array}{l}\text { Unreliable en- } \\
\text { ergy supply and } \\
\text { no emergency } \\
\text { energy backup. }\end{array}$ & $\begin{array}{l}\text { EBC (electric- } \\
\text { ity use). }\end{array}$ & \\
\hline
\end{tabular}


Table E1. Continued.

\begin{tabular}{|c|c|c|c|c|c|c|c|c|}
\hline System & $\begin{array}{l}\text { Sustainability } \\
\text { characteristics }\end{array}$ & $\begin{array}{l}\text { Sustainability } \\
\text { criteria }\end{array}$ & $\begin{array}{l}\text { General de- } \\
\text { scription }\end{array}$ & Sustainable & Under pressure & Unsustainable & $\begin{array}{l}\text { Suggestions for } \\
\text { general data } \\
\text { sources }\end{array}$ & $\begin{array}{l}\text { Reference for } \\
\text { general data } \\
\text { sources }\end{array}$ \\
\hline & & $\begin{array}{l}\text { Use of renew- } \\
\text { able energy }\end{array}$ & $\begin{array}{lr}\text { Use of } & \text { renew- } \\
\text { able } & \text { energy } \\
\text { sources } & \text { (gen- } \\
\text { erated } & \text { or } \\
\text { acquired } & \text { green } \\
\text { energy). } & \end{array}$ & $\begin{array}{l}\text { All used energy } \\
\text { is renewable } \\
\text { energy. }\end{array}$ & $\begin{array}{l}\text { A total of }> \\
50 \% \text { renewable } \\
\text { energy is used. }\end{array}$ & $\begin{array}{l}\text { A total of < } \\
50 \% \text { renewable } \\
\text { energy. }\end{array}$ & $\begin{array}{l}\text { IWA; pH7 en- } \\
\text { ergy recovery. }\end{array}$ & $\begin{array}{l}\text { Alegre } \\
\text { et al. (2006). }\end{array}$ \\
\hline \multirow[t]{8}{*}{$\begin{array}{l}\text { Socio- } \\
\text { economic } \\
\text { system }\end{array}$} & \multirow[t]{5}{*}{$\begin{array}{l}\text { Drinking water } \\
\text { availability }\end{array}$} & $\begin{array}{l}\text { Percentage } \\
\text { of connected } \\
\text { households }\end{array}$ & $\begin{array}{l}\text { Households } \\
\text { directly con- } \\
\text { nected to } \\
\text { drinking water } \\
\text { supply system. }\end{array}$ & $\begin{array}{l}\text { A total of }> \\
95 \% .\end{array}$ & $\begin{array}{l}\text { A total of } 80- \\
95 \% .\end{array}$ & $\begin{array}{l}\text { A total of }< \\
80 \% .\end{array}$ & $\begin{array}{l}\text { IWA; QS3 } \\
\text { population } \\
\text { coverage. }\end{array}$ & $\begin{array}{l}\text { Alegre } \\
\text { et al. (2006). }\end{array}$ \\
\hline & & $\begin{array}{l}\text { Drinking water } \\
\text { service quality }\end{array}$ & $\begin{array}{l}\text { Continuity } \\
\text { and quality of } \\
\text { supply (local } \\
\text { scale). }\end{array}$ & $\begin{array}{l}\text { Continuity } \\
\text { and quality } \\
\text { of drinking } \\
\text { water supply } \\
\text { guaranteed } \\
24 / 7 \text {. }\end{array}$ & $\begin{array}{l}\text { Continuity } \\
\text { of drinking } \\
\text { water supply or } \\
\text { quality under } \\
\text { pressure at } \\
\text { peak demand. }\end{array}$ & $\begin{array}{l}\text { Drinking water } \\
\text { quality and } \\
\text { supply con- } \\
\text { tinuity not } \\
\text { guaranteed. }\end{array}$ & $\begin{array}{l}\text { IWA QS12 con- } \\
\text { tinuity of sup- } \\
\text { ply; QS18 qual- } \\
\text { ity of supplied } \\
\text { water. }\end{array}$ & $\begin{array}{l}\text { Alegre } \\
\text { et al. (2006). }\end{array}$ \\
\hline & & $\begin{array}{l}\text { Drinking water } \\
\text { tariff }\end{array}$ & $\begin{array}{l}\text { Average water } \\
\text { charges without } \\
\text { public charges } \\
\text { (company } \\
\text { scale). }\end{array}$ & $\begin{array}{l}\text { A total of } \\
<\text { EUR } 1 \mathrm{~m}^{-3}\end{array}$ & $\begin{array}{l}\text { A total of } \\
\text { EUR } 1-2 \mathrm{~m}^{-3} \text {. }\end{array}$ & $\begin{array}{l}\text { A total of } \\
>\text { EUR } 2 \mathrm{~m}^{-3}\end{array}$ & $\begin{array}{lr}\text { IWA; } & \text { Fi28 } \\
\text { average } & \text { wa- } \\
\text { ter charges } \\
\text { for direct } \\
\text { consumption. }\end{array}$ & $\begin{array}{l}\text { Alegre } \\
\text { et al. (2006). }\end{array}$ \\
\hline & & $\begin{array}{l}\text { Water-saving } \\
\text { strategy }\end{array}$ & $\begin{array}{l}\text { Water-saving } \\
\text { strategy to } \\
\text { reduce average } \\
\text { water demand } \\
\text { in litre per } \\
\text { person per } \\
\text { day (national } \\
\text { scale). }\end{array}$ & $\begin{array}{l}\text { Effective water- } \\
\text { saving strategy } \\
\text { resulting in an } \\
\text { average water } \\
\text { demand }<1001 \\
\text { per person per } \\
\text { day. }\end{array}$ & $\begin{array}{l}\text { Water-saving } \\
\text { strategy aiming } \\
\text { to reduce the } \\
\text { average water } \\
\text { demand of } \\
100-2001 \text { per } \\
\text { person per day. }\end{array}$ & $\begin{array}{l}\text { No water- } \\
\text { saving strategy. }\end{array}$ & $\begin{array}{l}\text { SSI (sufficient } \\
\text { to drink). }\end{array}$ & $\begin{array}{l}\text { Van der Kerk } \\
\text { and Manuel } \\
(2008) \text {. }\end{array}$ \\
\hline & & $\begin{array}{l}\text { Water safety } \\
\text { protocols }\end{array}$ & $\begin{array}{l}\text { Are there wa- } \\
\text { ter safety pro- } \\
\text { tocols or wa- } \\
\text { ter safety plans } \\
\text { to safeguard the } \\
\text { drinking water } \\
\text { supply? }\end{array}$ & $\begin{array}{l}\text { Water safety } \\
\text { protocols fully } \\
\text { cover the } \\
\text { drinking water } \\
\text { supply, and the } \\
\text { organization } \\
\text { is performing } \\
\text { accordingly. }\end{array}$ & $\begin{array}{l}\text { There are } \\
\text { safety proto- } \\
\text { cols, but these } \\
\text { only cover part } \\
\text { of the drinking } \\
\text { water supply } \\
\text { or are not fully } \\
\text { performed. }\end{array}$ & $\begin{array}{l}\text { There are no } \\
\text { safety proto- } \\
\text { cols. }\end{array}$ & $\begin{array}{l}\text { Drinking water } \\
\text { company's in- } \\
\text { formation. }\end{array}$ & $\begin{array}{l}\text { E.g. Dutch } \\
\text { Government } \\
\text { (2009a). }\end{array}$ \\
\hline & \multirow[t]{3}{*}{$\begin{array}{l}\text { Water } \\
\text { governance }\end{array}$} & $\begin{array}{l}\text { Availability of } \\
\text { (drinking) wa- } \\
\text { ter legislation } \\
\text { and policies }\end{array}$ & $\begin{array}{l}\text { Is there ad- } \\
\text { equate leg- } \\
\text { islation on } \\
\text { drinking water } \\
\text { supply, and is } \\
\text { there enforce- } \\
\text { ment of this } \\
\text { legislation? }\end{array}$ & $\begin{array}{l}\text { There is } \\
\text { adequate leg- } \\
\text { islation on } \\
\text { drinking water } \\
\text { supply com- } \\
\text { bined with } \\
\text { sufficient en- } \\
\text { forcement by } \\
\text { legal authori- } \\
\text { ties. }\end{array}$ & $\begin{array}{l}\text { There is legis- } \\
\text { lation on drink- } \\
\text { ing water sup- } \\
\text { ply but limited } \\
\text { or no enforce- } \\
\text { ment by legal } \\
\text { authorities. }\end{array}$ & $\begin{array}{l}\text { There is no } \\
\text { legislation and } \\
\text { enforcement on } \\
\text { drinking water } \\
\text { supply. }\end{array}$ & $\begin{array}{l}\text { SSI (good } \\
\text { governance); } \\
\text { national and lo- } \\
\text { cal legislation. }\end{array}$ & $\begin{array}{l}\text { Van der Kerk } \\
\text { and Manuel } \\
(2008) \text {. }\end{array}$ \\
\hline & & $\begin{array}{l}\text { Compliance of } \\
\text { drinking water } \\
\text { supplier }\end{array}$ & $\begin{array}{l}\text { Are the re- } \\
\text { quired permits } \\
\text { available, and } \\
\text { is the facility } \\
\text { compliant with } \\
\text { the permit } \\
\text { requirements? }\end{array}$ & $\begin{array}{l}\text { All permits } \\
\text { are available, } \\
\text { and the facility } \\
\text { is compliant } \\
\text { with the permit } \\
\text { requirements. }\end{array}$ & $\begin{array}{l}\text { The permits } \\
\text { are available, } \\
\text { but the facility } \\
\text { is not fully } \\
\text { compliant with } \\
\text { the permit } \\
\text { requirements. }\end{array}$ & $\begin{array}{l}\text { There is a lack } \\
\text { of adequate } \\
\text { drinking water } \\
\text { supply leg- } \\
\text { islation, and } \\
\text { drinking water } \\
\text { suppliers only } \\
\text { follow their } \\
\text { company's } \\
\text { standard. }\end{array}$ & $\begin{array}{l}\text { SSI (good gov- } \\
\text { ernance); per- } \\
\text { mits; TRUST } \\
\text { framework for } \\
\text { Urban Water } \\
\text { Cycle Sys- } \\
\text { tems (UWCS) } \\
\text { sustainability } \\
\text { (G1-G4). }\end{array}$ & $\begin{array}{l}\text { Van der Kerk } \\
\text { and } \text { Manuel } \\
(2008) \text {. }\end{array}$ \\
\hline & & $\begin{array}{l}\text { Decision- } \\
\text { making process } \\
\text { by (local) } \\
\text { authorities }\end{array}$ & $\begin{array}{l}\text { Are local } \\
\text { stakeholders } \\
\text { involved in } \\
\text { decisions on } \\
\text { drinking water } \\
\text { supply or the } \\
\text { water system? }\end{array}$ & $\begin{array}{l}\text { Local stake- } \\
\text { holders are } \\
\text { involved in } \\
\text { the planning } \\
\text { process and } \\
\text { can participate } \\
\text { in licensing } \\
\text { procedures. }\end{array}$ & $\begin{array}{l}\text { Local stake- } \\
\text { holders are not } \\
\text { involved in the } \\
\text { planning pro- } \\
\text { cess and cannot } \\
\text { participate } \\
\text { in licensing } \\
\text { procedures. }\end{array}$ & $\begin{array}{l}\text { Local stake- } \\
\text { holders cannot } \\
\text { easily be in- } \\
\text { volved in } \\
\text { the decision- } \\
\text { making pro- } \\
\text { cess. }\end{array}$ & SDG 6.b. & UN (2015). \\
\hline
\end{tabular}


Table E1. Continued.

\begin{tabular}{|c|c|c|c|c|c|c|c|c|}
\hline System & $\begin{array}{l}\text { Sustainability } \\
\text { characteristics }\end{array}$ & $\begin{array}{l}\text { Sustainability } \\
\text { criteria }\end{array}$ & $\begin{array}{l}\text { General de- } \\
\text { scription }\end{array}$ & Sustainable & Under pressure & Unsustainable & $\begin{array}{l}\text { Suggestions for } \\
\text { general data } \\
\text { sources }\end{array}$ & $\begin{array}{l}\text { Reference for } \\
\text { general data } \\
\text { sources }\end{array}$ \\
\hline & & $\begin{array}{l}\text { Local stake- } \\
\text { holder interests }\end{array}$ & $\begin{array}{l}\text { Does the lo- } \\
\text { cal authority } \\
\text { actively weigh } \\
\text { stakeholder } \\
\text { interests in } \\
\text { the decision- } \\
\text { making pro- } \\
\text { cess? }\end{array}$ & $\begin{array}{l}\text { Stakeholders } \\
\text { are involved in } \\
\text { the decision- } \\
\text { making process } \\
\text { and stakeholder } \\
\text { interests must } \\
\text { legally be taken } \\
\text { into account in } \\
\text { the licensing } \\
\text { process. }\end{array}$ & $\begin{array}{l}\text { Stakeholder } \\
\text { interests must } \\
\text { be taken into } \\
\text { account in } \\
\text { the licensing } \\
\text { process. }\end{array}$ & $\begin{array}{l}\text { The interests } \\
\text { of (some) local } \\
\text { stakeholders } \\
\text { are not ac- } \\
\text { counted for } \\
\text { by the local } \\
\text { authorities. }\end{array}$ & $\begin{array}{l}\text { SDG } 6 . b ; \text { na- } \\
\text { tional or local } \\
\text { legislation. }\end{array}$ & UN (2015). \\
\hline & & $\begin{array}{l}\text { Emergency risk } \\
\text { caused by hu- } \\
\text { man activities } \\
\text { or conflicts }\end{array}$ & $\begin{array}{l}\text { Is there emer- } \\
\text { gency risk } \\
\text { caused by hu- } \\
\text { man activities } \\
\text { or conflicts? }\end{array}$ & $\begin{array}{l}\text { There is, in } \\
\text { general, no } \\
\text { serious emer- } \\
\text { gency risk } \\
\text { caused by hu- } \\
\text { man activities } \\
\text { or conflicts. }\end{array}$ & $\begin{array}{l}\text { There is a low } \\
\text { emergency risk } \\
\text { caused by hu- } \\
\text { man activities. }\end{array}$ & $\begin{array}{l}\text { There is an evi- } \\
\text { dent emergency } \\
\text { risk caused } \\
\text { by human } \\
\text { activities or } \\
\text { conflicts. }\end{array}$ & SDG 16. & UN (2015). \\
\hline & $\begin{array}{l}\text { Land and water } \\
\text { use }\end{array}$ & $\begin{array}{l}\text { Land use (in- } \\
\text { cluding subsur- } \\
\text { face use) }\end{array}$ & $\begin{array}{l}\text { Is land or sub- } \\
\text { surface use in } \\
\text { the area posing } \\
\text { a threat to the } \\
\text { drinking water } \\
\text { supply? }\end{array}$ & $\begin{array}{l}\text { The impact } \\
\text { of land or } \\
\text { subsurface use } \\
\text { is limited due } \\
\text { to low-risk } \\
\text { use or because } \\
\text { the drinking } \\
\text { water supply is } \\
\text { well protected } \\
\text { against the } \\
\text { impact. }\end{array}$ & $\begin{array}{l}\text { The land or } \\
\text { subsurface use } \\
\text { forms a poten- } \\
\text { tial risk to the } \\
\text { drinking water } \\
\text { supply but is } \\
\text { regulated. }\end{array}$ & $\begin{array}{l}\text { The land or } \\
\text { subsurface use } \\
\text { is affecting the } \\
\text { drinking water } \\
\text { supply. }\end{array}$ & $\begin{array}{l}\text { E.g. status of } \\
\text { water bodies } \\
\text { according to } \\
\text { European Wa- } \\
\text { ter Framework } \\
\text { Directive. }\end{array}$ & $\begin{array}{l}\text { European } \\
\text { Union (2000). }\end{array}$ \\
\hline & & $\begin{array}{l}\text { Water use for } \\
\text { other purposes } \\
\text { than drinking } \\
\text { water }\end{array}$ & $\begin{array}{l}\text { Does water use } \\
\text { in the area pose } \\
\text { a threat to the } \\
\text { drinking water } \\
\text { supply? }\end{array}$ & $\begin{array}{l}\text { In general, } \\
\text { there is suf- } \\
\text { ficient water } \\
\text { available for all } \\
\text { functions, and } \\
\text { water quality is } \\
\text { not affected by } \\
\text { water use. }\end{array}$ & $\begin{array}{l}\text { In extreme } \\
\text { situations, the } \\
\text { available water } \\
\text { resources are } \\
\text { limited and } \\
\text { must be fairly } \\
\text { distributed } \\
\text { between wa- } \\
\text { ter users or } \\
\text { water quality } \\
\text { deteriorates. }\end{array}$ & $\begin{array}{l}\text { There is } \\
\text { constantly } \\
\text { insufficient } \\
\text { water available } \\
\text { for all water } \\
\text { users, and/or } \\
\text { water quality } \\
\text { deterioration } \\
\text { occurs due to } \\
\text { various water } \\
\text { uses. }\end{array}$ & $\begin{array}{l}\text { E.g. status of } \\
\text { water bodies } \\
\text { according to } \\
\text { European Wa- } \\
\text { ter Framework } \\
\text { Directive. }\end{array}$ & $\begin{array}{l}\text { European } \\
\text { Union (2000). }\end{array}$ \\
\hline & & $\begin{array}{l}\text { Regulations on } \\
\text { land and water } \\
\text { use }\end{array}$ & $\begin{array}{l}\text { Are there reg- } \\
\text { ulations on } \\
\text { land use and } \\
\text { underground } \\
\text { activities to } \\
\text { protect the } \\
\text { local drink- } \\
\text { ing water } \\
\text { abstraction? }\end{array}$ & $\begin{array}{l}\text { There are } \\
\text { regulations } \\
\text { to remove } \\
\text { unwanted ac- } \\
\text { tivities from } \\
\text { the recharge } \\
\text { area to pro- } \\
\text { tect the local } \\
\text { drinking water } \\
\text { abstraction. }\end{array}$ & $\begin{array}{l}\text { There are } \\
\text { regulations } \\
\text { to prevent } \\
\text { new unwanted } \\
\text { activities by } \\
\text { using the stand } \\
\text { still/step for- } \\
\text { ward principle. }\end{array}$ & $\begin{array}{l}\text { There are no } \\
\text { regulations } \\
\text { to protect the } \\
\text { local drink- } \\
\text { ing water } \\
\text { abstraction. }\end{array}$ & $\begin{array}{l}\text { (Inter-) national } \\
\text { legislation; } \\
\text { TRUST Frame- } \\
\text { work for } \\
\text { UWCS sus- } \\
\text { tainability } \\
\text { (G1-G4). }\end{array}$ & $\begin{array}{l}\text { E.g. Dutch } \\
\text { Government } \\
(2009 b) \text {. }\end{array}$ \\
\hline & & $\begin{array}{l}\text { Limitations in } \\
\text { land or water } \\
\text { use }\end{array}$ & $\begin{array}{l}\text { Is the presence } \\
\text { of the facility } \\
\text { a significant } \\
\text { impediment } \\
\text { for current or } \\
\text { future land use } \\
\text { or underground } \\
\text { activities? }\end{array}$ & $\begin{array}{l}\text { The drink- } \\
\text { ing water } \\
\text { supply does } \\
\text { not present } \\
\text { a significant } \\
\text { impediment } \\
\text { for land or } \\
\text { subsurface use. }\end{array}$ & $\begin{array}{l}\text { The drinking } \\
\text { water supply } \\
\text { limits future } \\
\text { land use or } \\
\text { underground } \\
\text { activities. }\end{array}$ & $\begin{array}{l}\text { The drinking } \\
\text { water supply } \\
\text { is a significant } \\
\text { impediment } \\
\text { for current and } \\
\text { future land use } \\
\text { or underground } \\
\text { activities. }\end{array}$ & $\begin{array}{l}\text { E.g. status of } \\
\text { water bodies } \\
\text { according to } \\
\text { European Wa- } \\
\text { ter Framework } \\
\text { Directive. }\end{array}$ & $\begin{array}{l}\text { European } \\
\text { Union (2000). }\end{array}$ \\
\hline & & $\begin{array}{l}\text { Financial } \\
\text { compensation } \\
\text { for economic } \\
\text { damage from } \\
\text { the impact of } \\
\text { abstraction or } \\
\text { limitations in } \\
\text { land use }\end{array}$ & $\begin{array}{l}\text { Is there fi- } \\
\text { nancial com- } \\
\text { pensation of } \\
\text { economic } \\
\text { damage from } \\
\text { the impact of } \\
\text { abstraction or } \\
\text { limitations to } \\
\text { land use? }\end{array}$ & $\begin{array}{l}\text { Financial com- } \\
\text { pensation of } \\
\text { economic dam- } \\
\text { age caused by } \\
\text { the drinking } \\
\text { water supply } \\
\text { is organized } \\
\text { based on } \\
\text { legislation. }\end{array}$ & $\begin{array}{l}\text { Drinking wa- } \\
\text { ter suppliers } \\
\text { financially } \\
\text { compensate } \\
\text { for economic } \\
\text { damage based } \\
\text { on bilateral } \\
\text { agreements. }\end{array}$ & $\begin{array}{l}\text { There is } \\
\text { financial com- } \\
\text { pensation of } \\
\text { economic dam- } \\
\text { age caused by } \\
\text { the drinking } \\
\text { water supply } \\
\text { company. }\end{array}$ & $\begin{array}{l}\text { National or lo- } \\
\text { cal legislation. }\end{array}$ & $\begin{array}{l}\text { E.g. Dutch } \\
\text { Government } \\
(2009 b) \text {. }\end{array}$ \\
\hline
\end{tabular}


Data availability. The source data used for the illustrations of the cases are available upon request.

Author contributions. JvE, PH, and EvS conceptualized the study and developed the methodology. JvE curated the data, generated the visualizations, led the investigation, and wrote the original draft. All co-authors reviewed and edited the paper. PH, EvS, AJT, and RU supervised the research (see the CRediT taxonomy for explanations of terms).

Competing interests. The first author performed the research and was partially funded by Vitens, where she is employed. She had carte blanche with respect to the content of the research.

Acknowledgements. We are indebted to Vitens staff, Maarten Fleuren and Martin de Jonge, for their data collection for the illustrations of the analysed drinking water supply cases, and to Vitens staff, Mark de Vries, Henk Hunneman, and Rian Kloosterman, for cross-checking the results of the case analysis. We thank the two anonymous referees for their comments that helped to further improve the paper.

Review statement. This paper was edited by Luuk Rietveld and reviewed by two anonymous referees.

\section{References}

Alegre, H., Baptiste, J. M., Cabrera Jr., E., Cubillo, F., Duarte, P., Hirner, W., Merkel, W., and Pareno, R.: Performance Indicators for Water Supply Services, in: Manual of Best Practice, IWA Publishing, London, UK, 2006.

Baggelaar, P. K. and Geudens, P. J. J. G.: Prognoses en scenario's drinkwatergebruik in Nederland (Prognoses and scenarios for drinking water use in the Netherlands), ICASTAT, VEWIN, The Hague, the Netherlands, 2017.

Bauer, J. M. and Herder, P. M.: Designing Socio-Technical Systems. Philosophy of Technology and Engineering Sciences, NorthHolland, Amsterdam, the Netherlands, 2009.

Binder, C. R., Hinkel, J., Bots, P. W. G., and Pahl-Wostl, C.: Comparison of frameworks for analyzing social-ecological systems, Ecol. Soc., 18, 26-45, 2013.

Carr, E. R., Wingard, P. M., Yorty, S. C., Thompson, M. C., Jensen, N. K., and Roberson, J.: Applying DPSIR to sustainable development, Int. J Sust. Dev. World, 14, 543-555, 2009.

Cohen, D. A.: The Rationed City: The Politics of Water, Housing, and Land Use in Drought-Parched S ao Paulo, Public Culture, 28, 261-289, 2016.

Dutch Government: Drinkwaterwet (Dutch Drinking water Decree), BWBR0026338, The Hague, the Netherlands, 2009a.

Dutch Government: Waterwet (Dutch Decree on Water), BWBR0025458, The Hague, the Netherlands, 2009b.

Ekins, P., Gupta, J., and Boileau, P.: Global Environment Outlook GEO-6: Healthy Planet, Healthy People. Global Environment
Outlook, United Nations Environment Programme, Cambridge, UK, 2019.

European Benchmarking Co-operation: Learning from international best practices; 2017 Water and Wastewater Benchmark, EBC, The Hague, the Netherlands, 2017.

European Environment Agency: European waters Assessment of status and pressures 2018, Luxembourg, 2018.

European Union: EU Water Framework Directive, in: Official Journal of the European Communities, edited by: EUROPEAN UNION, Brussels, Belgium, 2000.

Eurostat: Environmental indicators: Typology and overview, Technical Report N0. 25, European Environment Agency, Copenhagen, Denmark, 1999.

Gleeson, T. and Wada, Y.: Assessing regional groundwater stress for nations using multiple data sources with the groundwater footprint, Environ. Res. Lett., 8, 044010, https://doi.org/10.1088/1748-9326/8/4/044010, 2013.

Hashimoto, T., Stedinger, J. R., and Loucks, D. P.: Reliability, Resiliency, and Vulnerability Criteria For Water Resource System Performance Evaluation, Water Resour. Res., 18, 14-20, 1982.

Hellegers, P. and Leflaive, X.: Water allocation reform: what makes it so difficult?, Water Int., 40, 273-285, 2015.

Janza, M.: A decision support system for emergency response to groundwater resource pollution in an urban area (Ljubljana, Slovenia), Environ. Earth Sci., 73, 3763-3774, 2015.

Jorgensen, L. F. and Stockmarr, J.: Groundwater monitoring in Denmark: Characteristics, perspectives and comparison with other countries, Hydrogeol. J., 17, 827-842, 2009.

Kools, S., Van Loon, A., Sjerps, R., and Rosenthal, L.: The quality of drinking water resources in the Netherlands, edited by: KWR, KWR Report, KWR, Nieuwegein, the Netherlands, 2019.

Liu, J., Mooney, H., Hull, V., Davis, S. J., Gaskell, J., Hertel, T., Lubchenco, J., Seto, K. C., Gleick, P., Kremen, C., and Li, S.: Sustainability. Systems integration for global sustainability, Science, 347, 1258832, https://doi.org/10.1126/science.1258832, 2015.

Loucks, D. P.: Sustainable Water Resources Management, Water Int., 25, 3-10, 2000.

Loucks, D. P., Van Beek, E., Stedinger, J. R., Dijkman, J. P., and Villars, M. T.: Water resource systems planning and management: an introduction to Methods, Models and Applications, Springer, Deltares and UNESCO-IHE, Cham, Switzerland, 2017.

Melese, Y. G., Heijnen, P. W., Stikkelman, R. M., and Herder, P. M.: Exploring for real options during CCS networks conceptual design to mitigate effects of path-dependency and lock-in, Int. J. Greenh. Gas Con., 42, 16-25, 2015.

Mendizabal, I., Baggelaar, P. K., and Stuyfzand, P. J.: Hydrochemical trends for public supply well fields in the Netherlands (18982008), natural backgrounds and upscaling to groundwater bodies, J. Hydrol., 450-451, 279-292, 2012.

Ministry of Infrastructure and Environment and Ministry of Economic Affairs and Climate Policy: Nederland beter weerbaar tegen droogte; Eindrapportage Beleidstafel Droogte (the Netherlands more resilient to drought; final report policy table drought), The Hague, the Netherlands, 2019.

Napoli, C. and Garcia-Tellez, B.: A framework for understanding energy for water, Int. J. Water Resour. D, 32, 339-361, 2016. 
Ness, B., Urbel-Piirsalu, E., Anderberg, S., and Olsson, L.: Categorising tools for sustainability assessment, Ecol. Econ., 60, 498-508, 2007.

Pahl-Wostl, C.: Towards sustainability in the water sector - The importance of human actors and processes of social learning, Aquat. Sci., 64, 394-411, 2002.

Pahl-Wostl, C.: Water Governance in the Face of Global Change; From understanding to transformation, Springer, London, UK, 2015.

Pant, L. P., Adhikari, B., and Bhattarai, K. K.: Adaptive transition for transformations to sustainability in developing countries, Curr. Opin. Env. Sust., 14, 206-212, 2015.

Singh, R. K., Murty, H. R., Gupta, S. K., and Dikshit, A. K.: An overview of sustainability assessment methodologies, Ecol. Indic., 15, 281-299, 2012.

Smith, A. and Stirling, A.: The Politics of Social-ecological Resilience and Sustainable Socio-technical Transitions, Ecol. Soc., 15, 11, available at: https://www.researchgate.net/publication/ 45227241_The_Politics_of_Social-ecological_Resilience_ and_Sustainable_Socio-technical_Transitions (last access: 18 January 2021), 2010.

Sorensen, P.: The chronic water shortage in Cape Town and survival strategies, Int. J. Environ. Stud., 74, 515-527, 2017.

Teuling, A. J.: A hot future for European droughts, Nat. Clim. Change, 8, 364-365, 2018.

UN: Indicators of Sustainable Development: Guidelines and Methodologies, Economic and Social Affairs, United Nations, New York, USA, 2007.

UN: Transforming our world: The 2030 Agenda for Sustainable Development, United Nations, New York, USA, 2015.

UN: Sustainable Development Goal 6 Synthesis Report 2018 on Water and Sanitation, edited by: Water, U., United Nations, New York, USA, 2018.

UNESCAP: Economic and social survey of Asia and the Pacific 2009; Addressing triple threats to development, edited by: United Nations Economic and Social Commission for Asia and the Pacific, ST/ESCAP/2522, United Nations Economic and Social Commission for Asia and the Pacific, Bangkok, Thailand, 2009.

UNICEF and WHO: Progress on Sanitation and Drinking Water; 2015 Update and MDG Assessment, NLM classification: WA 670, UNICEF and World Health Organization, New York, USA, 2015.

Van den Brink, C. and Wuijts, S.: Towards an effective protection of groundwater resources: putting policy into practice with the drinking water protection file, Water Policy, 18, 635-653, 2016.

Van der Aa, N. G. F. M., Tangena, B. H., Wuijts, S., and De Nijs, A. C. M.: Scenario's drinkwatervraag 2015-2040 en beschikbaarheid bronnen; verkenning grondwatervoorraden voor drinkwater (Scenarios drinking water demand 2015-2040 and water resources availability; exploratory study on groundwater resources for drinking water), RIVM, Bilthoven, the Netherlands, 2015.
Van der Kerk, G. and Manuel, A.: A comprehensive index for a sustainable society: The SSI - the Sustainable Society Index, Ecol. Econ., 66, 228-242, 2008.

Van Engelenburg, J., Hueting, R., Rijpkema, S., Teuling, A. J., Uijlenhoet, R., and Ludwig, F.: Impact of Changes in Groundwater Extractions and Climate Change on Groundwater-Dependent Ecosystems in a Complex Hydrogeological Setting, Water Resour. Manag., 32, 259-272, 2018.

Van Engelenburg, J., Van Slobbe, E., and Hellegers, P.: Towards sustainable drinking water abstraction: an integrated sustainability assessment framework to support local adaptation planning, J. Integr. Environ. Sci., 16, 89-122, 2019.

Van Engelenburg, J., De Jonge, M., Rijpkema, S., Van Slobbe, E., and Bense, V. F.: Hydrogeological evaluation of managed aquifer recharge in a glacial moraine complex using long-term groundwater data analysis, Hydrogeol. J., 28, 1787-1807, 2020.

Van Noordwijk, M., Speelman, E., Hofstede, G. J., Farida, A., Abdurrahim, A. Y., Miccolis, A., Hakim, A. L., Wamucii, C. N., Lagneaux, E., Andreotti, F., Kimbowa, G., Assogba, G. G. C., Best, L., Tanika, L., Githinji, M., Rosero, P., Sari, R. R., Satnarain, U., Adiwibowo, S., Ligtenberg, A., Muthuri, C., Pena-Claros, M., Purwanto, E., Van Oel, P., Rozendaal, D., Suprayogo, D., and Teuling, A. J.: Sustainable Agroforestry Landscape Management: Changing the Game, Land, 9, 243, https://doi.org/10.3390/land9080243, 2020.

Van Thiel, L.: Watergebruik thuis 2016 (Domestic water use 2016). TNO Nipo Report C8732; Kantar Public, Amsterdam, the Netherlands, 2017.

Vitens: Resiliently ahead; Long-term vision on our infrastructure 2016-2040, Vitens, Zwolle, the Netherlands, 2016.

WHO: Guidelines for drinking-water quality: fourth edition incorporating the first addendum, World Health Organization, Geneva, Switzerland, 2017.

WHO and UNICEF: Progress on drinking water, sanitation and hygiene, 2017 update and SDG Baselines, World Health Organization (WHO) and UNICEF, Geneva, Switzerland, 2017.

Wolters, H. A., Van den Born, G. J., Dammers, E., and Reinhard, S.: Deltascenario's voor de 21e eeuw, actualisering 2017 (Delta scenarios for the 21st century, actualisation 2017), Deltares, Utrecht, the Netherlands, 2018. 